\title{
Integrated algal and oil palm biorefinery as a model system for bioenergy co-generation with bioproducts and biopharmaceuticals
}

\author{
Mohd Azmuddin Abdullah ${ }^{1 *}$ (D) and Hanaa Ali Hussein ${ }^{2}$
}

\begin{abstract}
Background: There has been a greater call for greener and eco-friendly processes and bioproducts to meet the 2030's core agenda on 17 global sustainable development goals. The challenge lies in incorporating systems thinking with a comprehensive worldview as a guiding principle to develop the economy, whilst taking cognisance of the need to safeguard the environment, and to embrace the socio-cultural diversity dimension as an equal component. Any discussion on climate change, destruction of eco-system and habitat for wild life, poverty and starvation, and the spread of infectious diseases, must be addressed together with the emphasis on the development of cleaner energy, air and water, better management of resources and biodiversity, improved agro-practices for food production and distribution, and affordable health care, as the outcomes and key performance indicators to be evaluated. Strict regulation, monitoring and enforcement to minimize emission, pollution and wastage must also be put in place.

Conclusion: This review article focuses on the research and development efforts to achieve sustainable bioenergy production, environmental remediation, and transformation of agro-materials into value-added bioproducts through the integrated algal and oil palm biorefinery. Recent development in microalgal research with nanotechnology as anti-cancer and antimicrobial agents and for biopharmaceutical applications are discussed. The life-cycle analysis in the context of palm oil mill processes is evaluated. The way forward from this integrated biorefinery concept is to strive for inclusive development strategies, and to address the immediate and pressing problems facing the Planet and the People, whilst still reaping the Profit.
\end{abstract}

Keywords: Integrated biorefinery, Algae, Palm oil milling, Bioresource utilization, Bioenergy co-generation, Bioproducts

\section{Introduction}

Global carbon dioxide $\left(\mathrm{CO}_{2}\right)$ emissions from the fossil fuels have increased 15 times between 1900 and 2008 (Boden et al. 2010). This has prompted greater efforts to develop green technology and eco-friendly materials, to reduce over-dependence on fossil-based fuels and products, and green-house gas (GHG) emissions. Biorefineries aim to achieve efficient and sustainable utilization of

\footnotetext{
*Correspondence: joule1602@gmail.com; joule1602@yahoo.com

${ }^{1}$ Institute of Marine Biotechnology, Universiti Malaysia Terengganu,

21030 Kuala Nerus, Terengganu, Malaysia

Full list of author information is available at the end of the article
}

biomass resources for the generation of bioenergy and bioproducts (Budzianowski 2017). The biomass conversion processes and equipments are integrated to produce energy, fuels, power and heat, and marketable organic feed, food, chemicals and materials (IEA 2014; NREL 2015). The biorefineries may replace the power plants, or linked to the existing biofuel plants for new biofuels generation, or by re-equipping the existing biofuels with the new bioenergy facilities, or by setting up entirely new facilities, incorporating the processing of the bioresources (Budzianowski 2017; Laosiripojana et al. 2018). The basic principle is to reduce the total raw materials and the consumption of energy per production unit, 
with the materials being considered within the plant and energy recovery (Chemmangattuvalappil and $\mathrm{Ng} 2013$ ). As the platform for sustainable production route, the feedstock must be inexpensive and the processes must enable the extraction of bio-energy and bio-products at the highest and maximum possible range (Rathore et al. 2016).

Algae are resilience, versatile, and could withstand a variety of weathers and conditions, with less interference in the food supply chain as compared to the conventional oil seed crops (Brennan and Owende 2010; Clarens et al. 2010). Integrated algal biorefinery and palm oil milling (POM) have big potentials to meet the agenda of global sustainable development goals (SDGs) particularly in meeting the demand for affordable and clean energy, developing cities, and surrounding sustainable communities, and practising responsible consumption and production (Abdullah et al. 2016a, b, 2017a; b; Charmondusit et al. 2016; Gheewala et al. 2013). It is crucial to strive for optimal use of locally useful resources while reducing the costs and environmental effects (Pauli 2010). With the combined total of 64.2 million metric tons (MT), Indonesia (56.5\%) and Malaysia (27.9\%) are the world's largest producers of palm oil (Index Mundi 2019). The palm oil milling processes could generate large amount of biomass residues and effluents (Fig. 1). The fresh fruit bunch (FFB) palm oil is isolated through dry or wet milling methods. The wet method is mostly used which generates high amount of palm oil mill effluent (POME). This has created an environmental load because of the huge discharge of wastewater during the milling process. It is estimated that 5-7 tonnes of fresh water are needed to process 1 tonne of FFB, of which 50-79\% ends up in POME (Ohimain and Izah 2017). The residues generated, depending on the typical biomass of the fresh fruit bunches (FFBs) extraction rate (on wet basis percentage) are empty fruit bunches (EFBs) (22), mesocarp-fibres (MF) (13.5), and palm kernel-shells (PKS) (5.5) and POME (67) (Loh 2016). The development of an integrated refinery is essential for sustainable conversion of EFB, MF, PKS, and POME into high value products (Theo et al. 2017).These provide great resources for conversion into value-added products. Technologies such as composting, pelletizations, agglomeration, compression, pyrolysis, co-generation, enzymatic/acid/alkali digestion or autoclave/heat/steam treatment can be applied for the conversion of the residual biomass (Chiew and Shimada 2013; Nazir et al. 2013; Chang 2014). The shells and the fibres can be utilized for steam and electricity generation in the mill (Nasrin et al. 2008). The EFBs are re-used as
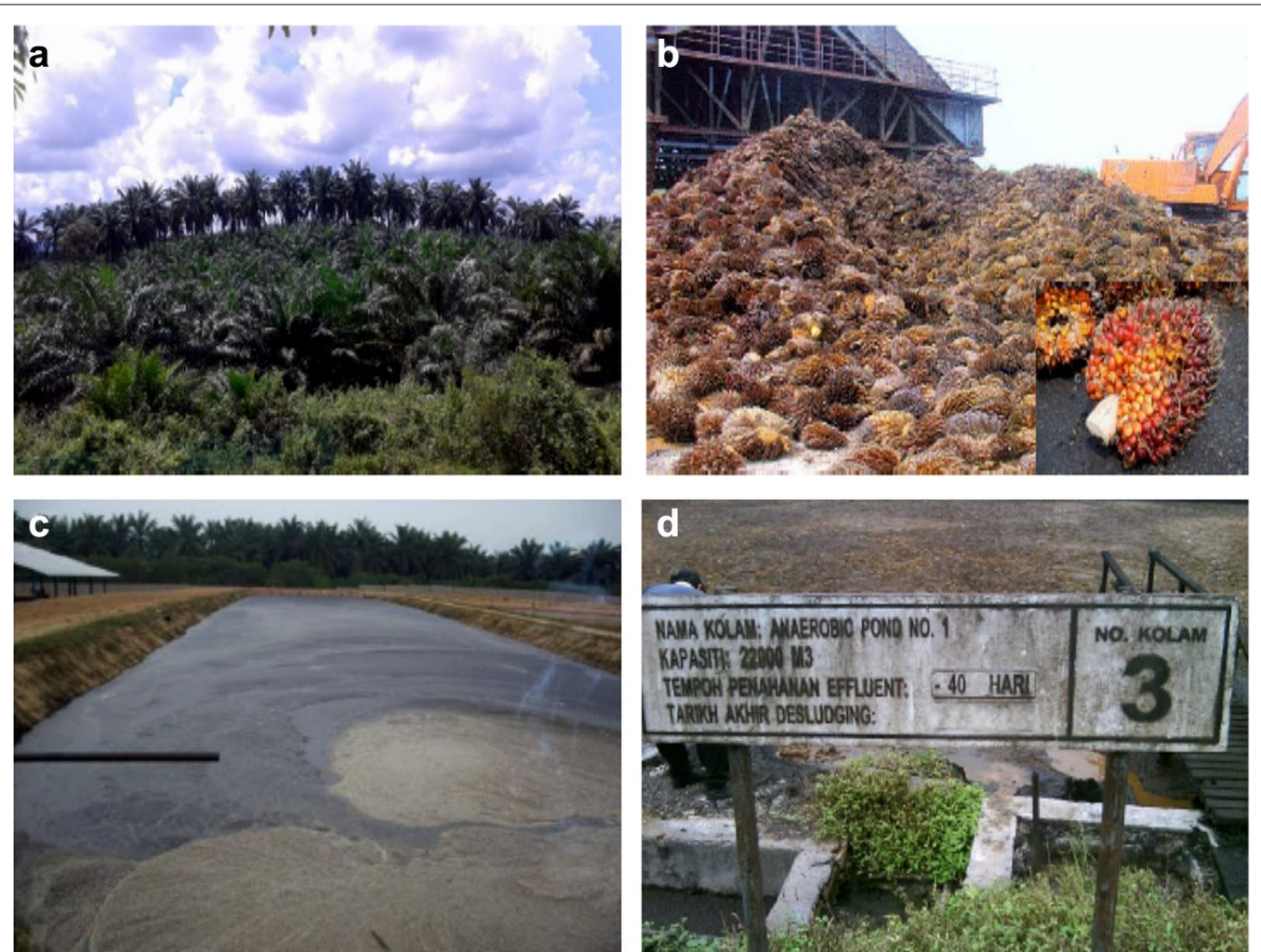

Fig. 1 Biomass and effluent generated by the palm oil industry: a oil palm plantation, b FFBs, c open pond, $\mathbf{d}$ anaerobic treatment pond 
fertilizers by mulching in the plantation or disposed of in the landfill or burnt to produce potash (Chavalparit et al. 2006). The palm kernel cakes are composted, or for animal feeds (Singh et al. 2010). The POME is normally treated in the ponding system in sequence, consisting of the anaerobic, facultative, and aerobic ponds, which all require low investment costs (Abdullah and Ahmad 2016). A new agro-production model based on the cocultivation of microalgal biomass within the POM setting will be attractive for regenerating biofuels (e.g. ethanol, methanol, bio-oil, and biodiesel) (Sawaengsak et al. 2014; Garcia-nunez et al. 2016), environmental remediation with biogas production, briquettes, biomass fuel pellet, and dried long fibres (Abdullah and Ahmad 2016; Abdullah et al. 2016a; Theo et al. 2017), conversion into valueadded biomaterials (Abdullah et al. 2016b; 2017b), and as a route to the production of high-value biocompounds and bioproducts (Abdullah et al. 2016a, 2017a).

There has been an increasing interest in the biologically active metabolites from natural sources for their beneficial effects on health (Herrero et al. 2013). This has led to the search for novel active pharmaceutical compounds and the development of novel drugs to treat various human diseases (Newman and Cragg 2012). Several clinically usable and commercially available drugs from natural products have shown potency as anti-tumour, antiallergy and anti-infection activity and capable of treating analgesia and cognitive diseases (Bhattacharjee 2016). Microalgae have the potential to improve health and cure many diseases (De Morais et al. 2015). Being one of the ancient living organisms on Earth, microalgae can grow in diverse habitats such as the desert and the sea (Stengel et al. 2011). This varied habitat leads to many biologically effective therapeutic metabolites as a response to multitude of stressors that can be extracted from the biomass or produced extracellularly (Bhagavathy et al. 2011). Microalgae is ideal as an alternative system to molecular pharming as they do not contain pathogens for human and are generally regarded as safe (GRAS) organisms. Microalgae can grow in axenic conditions in controlled bioreactors that could facilitate the production of biopharmaceuticals, and achieve the homogeneity of proteins, antibiotics and phytochemicals (Specht et al. 2010; Abdullah et al. 2016a, 2017a). The bioactive molecules extracted from microalgae have exhibited the ability to reduce or prevent diseases (Volk 2008). These compounds may be primary metabolites such as fatty acids, proteins, pigments and vitamins, or secondary metabolites such as the terpenoids or phenolics compounds (De Morais et al. 2015). Others include lipids, polysaccharides, antioxidants, carotenoids, chlorophylls, sterols, enzymes, flavonoids or small molecules of pharmaceutical and nutritional importance
(Priyadarshani and Rath 2012). Of great interest is in the co-application of natural products with nanotechnology to improve the therapeutic efficacy with reduced sideeffects; or enhance the bioactivities/antimicrobial activities of existing drugs/antibiotics (Hussein et al. 2020a, b). Optimal engineering involving microalgal biofuel production and the recovery of co-products, with the environmental and molecular factors, could trigger constitutive product accumulation including the lipids, carbohydrates and high-value bioproducts.

Algal cultivation for food and animal feed could meet the agenda of global food security. The global aquaculture production of farmed aquatic animals between 2001 and 2018 grew at $5.3 \%$ annually, on average, and the total fish production is projected to increase from 179 million tonnes in 2018, to 204 million tonnes in 2030. The global production of marine macroalgae has expanded from 10.6 million tonnes in 2000 , to 32.4 million tonnes in 2018 (FAO 2020). However, for large-scale production of algal biochemicals and biofuels, the development of low volume, high-value chemical products is needed. Currently, the microalgal manufacturing infrastructure has been focusing on the extraction of high-value products (IEA Bioenergy 2012). The annual production of microalgae is 5000 tonnes dry matter per year with the global turnover of around US\$1.25 $\times 10^{9}$ per year, while the macroalgal production is $7.5 \times 10^{6}$ tonnes dry matter per year with 4.8-fold higher global market than the microalgae (Pulz and Gross 2004). To achieve economic viability, the business model for fast adoption of algal technology is to use the entire biomass, with improved technology for cultivation and to focus the production on high lipid, protein and carbohydrate contents, with other valuable compounds such as fatty acids, pigments, antioxidants, vitamins, anti-microbial, toxins, sterols, nutraceuticals and pharmaceuticals (IEA Bioenergy 2012; Ubando et al. 2020). The production of bulk chemicals and energy from microalgae must be implemented at larger scale (increase of 3 orders of magnitude) and at much lower costs (a reduction by a factor of 10) (IEA Bioenergy 2012). Biorefinery is the way forward to green the economy and to achieve sustainability by achieving the balance between the environmental, societal and economic governance (Giraldo et al. 2020). The integrated biorefinery approach producing biofuels and value-added products has higher potential of gaining economic profitability (Rajesh Banu et al. 2020). Sequential extractions of products before anaerobic digestion, for example, could improve the methane yields and make the overall process more viable (Mhatre et al. 2019). Fractionation of algal biomass into major constituents-lipids, carbohydrates and proteins, and separation and purification into other valueadded bioproducts in a biorefinery would optimize the 
economics, whilst minimizing the energy, water, nutrients, land use and environmental footprint (Laurens et al. 2017; Abdullah and Hussein 2020). The process integration for the co-production of diverse products must therefore be evaluated such that newer products, applications and markets can be developed (Gajaria et al. 2017).

The aim of integrated algal and oil palm biorefinery is to achieve effective utilization of biomass resources, with efficient organizational and administrative procedures, goods, services, equipments and logistics, leading to increased economic value of multiple products including biofuels, biochemicals, biopharmaceuticals, and foodstuffs. These eventually could increase the utilization of renewable resources, whilst reducing the use of nonrenewable resources, and expand the storage, treatment and disposal of wastes (Giraldo et al. 2020). A cascading biorefinery can be developed to enhance the algal economic value chain through the valorization of proteins, lipids, starch/polysaccharides, vitamins and minerals for food, animal feed, biofuels and also multiple bioindustries (van Hal et al. 2014; Masarin et al. 2016; Bleakley and Hayes 2017; Gajaria et al. 2017). Biomass wastes and waste water generation will push the boundaries of conversion into value-added products, but the promotion of circular economy will be very much influenced by the socio-economic factors which are the major barriers in adopting biorefineries (Ubando et al. 2020). Despite the vast potential, the opportunities to valourize the wastes and waste water and extract economic values from palm oil mill and oil palm plantation have not been fully developed. Large amount of agro-industrial and industrial wastes can be recycled and reused as a nutrient supply for algal cultivation, and converted into bioenergy. The oil palm biomass can be pre-treated, and the bulk chemicals extracted and utilized for diverse applications. The wide spectrum of microalgal metabolites including alkaloids, polyphenols, flavonoids, and carotenoids, exhibiting a broad range of biological activities, must be exploited and refined for pharmaceutical industries. For these, the specific conditions must be developed and optimized such that algal utilization is fit for human consumption as food, or as feed for aquaculture (Abdullah et al. 2017a, b; Shah and Abdullah 2017).

This paper reviews the clean energy initiatives in oil and gas industries, the biorefinery concept based on the cultivation of algae and palm oil milling for the production of bioenergy, and the value-added bioproducts cogeneration, with the applications of bio/nanotechnology platform.

\section{Clean energy initiatives in oil and gas industries}

The initiatives made by the oil and gas industries in energy sector must be understood to better appreciate the need for adaptability and a smooth transition into the development of an integrated biorefinery. Efficient utilization of energy, higher supply and availability of clean fuels, elimination of pollutant emission and reduction of GHGs are attainable by utilizing Hydrogen $\left(\mathrm{H}_{2}\right)$ and Syngas (a mixture of $\mathrm{H}_{2}$ and $\mathrm{CO}$ ). Hydrocarbon fuels need a hydrocarbon fuel processing system such as catalytic steam reforming (CSR), partial oxidation and autothermal reforming (ATR), oxidative steam reforming, water-gas shift or preferential oxidation of natural gas, ethanol biogas, or biomass, for conversion into $\mathrm{H}_{2}$ or syngas fuel (Subramani et al. 2010; Kaiwen et al. 2018). The electrical power generation based on the syngas can be implemented through the conventional and advanced technologies involving natural gas combined cycle (NGCC) and integrated gasification combined cycle (IGCC) plants utilizing both gas and steam turbine, internal combustion engines (ICEs) for transportation and distributed power generation, solid oxide fuel cells (SOFCs) (Williams et al. 2006), and molten carbonate fuel cells (MCFCs) and the hybrid plants with turbines and fuel cells. The two most common methods to produce hydrogen are steam reforming of a natural gas and gasification of coal. The CSR technique produces $\mathrm{H}_{2}$-rich gas, from a hydrocarbon, or alcohol fuels and water, over a base metal, or noble metal-supported catalysts (Subramani et al. 2010). The gasification of coal is economically feasible but need to address the concerns on the environmental impacts and high $\mathrm{CO}_{2}$ emission. Natural gas has been the main feedstock for $\mathrm{H}_{2}$ production and the method is well-established, requiring low capital cost at $\$ 2.48-3.17 / \mathrm{kg} \mathrm{H}_{2}$. The transportation costs of natural gas are also lower than hydrogen (Bartels et al. 2010; Kaiwen et al. 2018). For environmentally effective route, the steam reforming of biogas to produce hydrogen and methanol is viable, which may reach the value of $\$ 0.27$ / $\mathrm{kWh}$ for $\mathrm{H}_{2}$ (Braga et al. 2013), and an estimated \$1.75/ gal for methanol (Hernandez and Martin 2016). Methanol, in turn, can be catalytically converted into other transportation fuels such as gasoline, dimethyl ether or biodiesel. Ethanol steam reforming is also attractive but the costs for $\mathrm{H}_{2}$ production can be influenced by the plant capacities, the catalysts and the ethanol feedstock. Low plant capacity can result in higher $\mathrm{H}_{2}$ selling price, and increasing the plant capacity by 100 -fold from 1500 $\mathrm{kg} /$ day can reduce the selling price to $\$ 2.69 / \mathrm{kg} \mathrm{H}_{2}$, but the capital cost may be increased. To compensate, the cost of catalysts can be made more acceptable and the total cost of hydrogen production reduced, if ethanol is sourced from the fermentation of biomass (Song and Ozkan 2010).

Methane produced from natural gas or biogas, has high calorific value, and is suitable for large-scale steam 
reforming route (Kaiwen et al. 2018). The important factors in the steam reforming of methane for $\mathrm{H}_{2}$ production are the reaction pressure, temperature, the selectivity of $\mathrm{H}_{2}$, and the $\mathrm{H}_{2} / \mathrm{CO}$ ratio (Farshchi Tabrizi et al. 2015); and the length of the reactor (Imran Aman et al. 2017). The combined steam reforming and dry reforming of methane exhibit lower char footprint, but requiring additional equipments, which incur higher total direction cost, as compared to the steam reforming alone (Gangadharan et al. 2012). The sorption enhanced steam methane reforming with in situ $\mathrm{CO}_{2}$ capture could be used for $\mathrm{H}_{2}$ production from natural gas, with high purity and GHG sequestration. The Ni-mayenite support system developed for the process exhibits good performance, while the combined sorbent catalyst material based on $\mathrm{Ni}-$ $\mathrm{CaO}$-mayenite is found to have the Ni catalytic activity lowered by the presence of $\mathrm{CaO}$ loading (Di Giuliano et al. 2017). The sorption enhanced steam reforming of methane in a network of fixed beds, with the integration of a SOFC, has been evaluated for power generation. The cost of $\mathrm{H}_{2}$ production with $\mathrm{CO}_{2}$ capture is levelled at $\$ 1.89 / \mathrm{kg}$, while the cost of $\mathrm{CO}_{2}$ avoided is USD $\$ 35.3 /$ tonne $\mathrm{CO}_{2}$. These are 1.5 and 1.7 -fold, respectively, lower than the cost of reforming without the sorption. The integration with the SOFC also levels the cost of electricity at $\$ 0.092 / \mathrm{kWh}$ with the cost of $\mathrm{CO}_{2}$ avoided at $\$ 43.5 /$ tonne $\mathrm{CO}_{2}$. These are comparable and 2.1-fold lower, respectively, than the natural gas-fired power plant with the carbon capture. The economic analyses further suggest the possibility of attaining higher revenue and the feasibility of implementing the sorption enhanced steam methane reforming, with the network of fixed beds integrated to the SOFC, for hydrogen production and $\mathrm{CO}_{2}$ capture, as an alternative to the natural gas-fired power plant (Diglio et al. 2017). The catalysts used in the steam reforming of methane for $\mathrm{H}_{2}$ production are mostly Ni-based, attributable to its high reactivity as compared to the natural catalyst. The important natural catalysts such as dolomite and olivine, have tremendous potential for application in the production of $\mathrm{H}_{2}$-rich gas and $\mathrm{CO}_{2}$ capture, but the efficiency may be lower than the Ni-based catalyst (Kaiwen et al. 2018).

The major drawback of steam reforming method is the high amount of unconverted hydrocarbon (tar) in the produced gas which necessitates further processing (Kaiwen et al. 2018), and the carbon deposition and catalyst deactivation. Further improvement in the catalyst development and reactor design are therefore required (Subramani et al. 2010). The hot and warm gas cleanup must be put in place for particle removal, carbonyl sulphide (COS) hydrolysis, acid gas cooling, sulphur and mercury removal and recovery, and $\mathrm{CO}_{2}$ sequestration. The char and fly ash can be removed by cyclone filters, ceramic or metal candle filters, or wet scrubbing. Sulphur compounds or hydrogen sulphide $\left(\mathrm{H}_{2} \mathrm{~S}\right)$ are poisonous to the catalysts, the fuel cell stacks, or the separation membrane for $\mathrm{H}_{2}$ purification. Ultradeep desulfurization of hydrocarbon fuels is required to reduce the sulphur contents to lower than $15 \mathrm{ppm}$ for diesel, or $30 \mathrm{ppm}$ for gasoline. The technologies for desulfurization include catalytic hydrodesulfurization (HDS), new design and properties of the catalyst, reactor, and the process, and multidesulfurization technologies such as adsorptive (ADS), oxidative (ODS), extractive (EDS) and biodesulfurization (BDS) (Nishioka et al. 1985; Tuan et al. 1994; Dicks 1996; Song and Ma 2010). The future lies in high efficiency and low emission technologies based on the NGCC, IGCC and hybrid fuel cell power plants (Song 2010; Wei et al. 2010). The syngas production and purification technologies are critical to gas-to-liquid (GTL) and biomassto-liquid (BTL) conversion systems. The syngas from solid and gaseous fuels can then be the feedstocks to synthesize liquid hydrocarbon fuels, methanol, dimethyl ether and ethanol for transportation vehicles (Song 2010). These should be the major considerations and become the basis for the transition into an integrated biorefinery.

\section{Integrated algal and oil palm biorefinery Bioenergy co-generation}

The clean development mechanism for energy sector may involve the renewable energy generation based on hydropower or biomass; the replacement of coal with natural gas or biomass; the improvement of energy efficiency by utilizing more efficient motors or equipments with cogeneration of heat and power; and the capture of biogas and methane to generate energy (Mekhilef et al. 2011). The oil palm industries have big potentials to be the next generation renewable energy providers and feedstocks for biorefineries. The oil palm tree has a higher efficiency of oil production at $4000 \mathrm{~kg} / \mathrm{ha}$ as compared to the sunflower, soybeans, peanuts, cotton, and rapeseed. The oil palm tree also has a relatively long economic lifespan of 25 to 30 years, with a reliable supply of oil production (Kurnia et al. 2016). The technologies to generate electrical energy from biomass sources may involve direct combustion of biomass such as EFB or mesocarp fibres; gasification of lignocellulosic biomass into hydrogen gas; pyrolysis; briquetting of EFB or palm kernel expeller (PKE) into solid fuels; and anaerobic digestion (Mekhilef et al. 2011). The EFBs can be converted into bioethanol by hydrolysis, fermentation, and distillation, or to bio-oil by rapid pyrolysis and gasification (Abdullah et al. 2011; Ishola et al. 2014). 


\section{Biodiesel}

Palm oil exhibits superior content (on the weight basis) of palmitic acid (C16:0) (45\%), as compared to other edible oils from soybean, sunflower, rapeseed, corn and coconut, but with comparable content of stearic acid (C18:0) (4\%), oleic (C18:1) (39\%), and lower linoleic acid (C18:2) (11\%). In comparison, Chlorella sp. shows $24-36 \%$ palmitic, $1-2 \%$ stearic, $13-17 \%$ oleic, and $33-41 \%$ linoleic acid (Zahan and Kano 2018). These are the fatty acids constituents normally associated with the transformation of oil into a high quality biodiesel. The refined crude palm oil (CPO) is transformed into methyl esters and used directly or blended with petroleum diesel. The transesterification method has also been developed for refined, bleached and deodorized (RBD) palm olein with methanol, in the presence of potassium hydroxide $(\mathrm{KOH})$ catalyst to achieve $62.5 \%$ yield, which is lower than that achievable with the palm oil (95.3\%) (Kareem 2017) and palm kernel oil (94.6\%) (Akhabue and Ogogo 2018). The derived biodiesel however shows comparable density of $884 \mathrm{~kg} / \mathrm{m}^{3}$, and kinematic viscosity of $4.56 \mathrm{~mm}^{2} / \mathrm{s}$ at 40 ${ }^{\circ} \mathrm{C}$, to the palm oil and palm kernel oil, although slightly higher than diesel at $850 \mathrm{~kg} / \mathrm{m}^{3}$ (Ishola et al. 2020). The cetane number attained at 48.91 is comparable to the ASTM standard, though slightly lower than diesel at 50 . The flash point of RBD palm olein biodiesel at $208{ }^{\circ} \mathrm{C}$, though in the middle between palm oil $\left(270{ }^{\circ} \mathrm{C}\right)$ and palm kernel oil $\left(162{ }^{\circ} \mathrm{C}\right)$, is far higher than diesel $\left(85^{\circ} \mathrm{C}\right)$, and the minimum of ASTM standard $\left(52{ }^{\circ} \mathrm{C}\right.$ ) (Hariram et al. 2018; Ishola et al. 2020). The biodiesel from non-edible oil source (Moringa oleifera) has been compared with palm biodiesel and diesel fuel. The palm and M. oleifera biodiesel and the blends, although meet the ASTM D6751 and EN14214, exhibit lower brake powers and higher brake specific fuel consumption at the $5 \%$ blends. However, the biodiesel at 5 and $10 \%$ blends of both oils have resulted in reduced average emissions of carbon monoxide and hydrocarbons, but with increased nitric oxide $\mathrm{CO}_{2}$ emissions, as compared to the diesel fuel (Mofijur et al 2014).

\section{Bioethanol}

EFB contains approximately $73.6 \%(w / w)$ holocellulose and the degradation of cellulose produces glucose as the main product which can be used for the conversion into bioethanol (Laosiripojana et al. 2018). Bioethanol production from lignocellulosic biomass requires pretreatment or delignification step to release cellulose and hemicellulose. The hydrolysis of cellulose and hemicellulose produces sugars which will be fermented to produce ethanol (Sukhang et al. 2020). The pretreatment of EFB with $1 \%(\mathrm{v} / \mathrm{v})$ dilute $\mathrm{H}_{2} \mathrm{SO}_{4}$ at $125^{\circ} \mathrm{C}$ for $90 \mathrm{~min}$, followed by $1 \%(\mathrm{w} / \mathrm{v}) \mathrm{NaOH}$ at $100{ }^{\circ} \mathrm{C}$ for $60 \mathrm{~min}$, removes more than $90 \%$ of hemicellulose and $50 \%$ of lignin. The delignified EFB at $5 \%(\mathrm{w} / \mathrm{v})$ is enzymatically hydrolysed for $72 \mathrm{~h}$ to attain about $485 \mathrm{mg} / \mathrm{g}$ glucose. The addition of Triton-X enhances the saccharification by $31.3 \%$. The fermentation of the derived sugar by Saccharomyces cerevisiae produces $12 \mathrm{~g} / \mathrm{L}$ of bioethanol with $89.1 \%$ theoretical yield within $24 \mathrm{~h}$ (Nurul Adela et al. 2014). The SSF of the oil palm frond (OPF) with Saccharomyces cerevisiae has been carried out for bioethanol production. The pretreatment of the OPF at $20 \%(\mathrm{w} / \mathrm{v})$ by presoaking in different acid or alkali, results in the cellulose yield of $37 \%$ in $2 \% \mathrm{H}_{2} \mathrm{SO}_{4}, 42 \%$ in $\mathrm{NaOH}$, and $49 \%$ in $2 \%$ $\mathrm{NaOH}$ in $\mathrm{H}_{2} \mathrm{O}_{2}$. The simultaneous saccharification by cellulase produces $45.72,55.73$ and $56.94 \mathrm{~g} / \mathrm{L}$ sugar yield, respectively, and the bioethanol production of 14.5, 15.0 and $17.2 \mathrm{~g} / \mathrm{L}$, respectively. With the total solids recovery of $82.11 \%$, containing $49 \%$ cellulose, and $37.6 \%$ enzyme digestibility, the $2 \% \mathrm{NaOH}$ in $\mathrm{H}_{2} \mathrm{O}_{2}$ is suggested to be the best pretreatment method (Kumneadklang et al. 2015). The acid-alkali pretreatment of EFB using a dilute acid of $0.2 \mathrm{M}$ sulphuric acid concentration $(12.5 \%(\mathrm{w} / \mathrm{v})), 121^{\circ} \mathrm{C}$ for $20 \mathrm{~min}$, has resulted in $72.1 \%$ cellulose, $3.24 \%$ hemicellulose, and $17.6 \%$ lignin. The optimal conditions for simultaneous saccharification and fermentation (SSF) by Klyveromyces marxinus are at $12.24 \%$ substrate, $\mathrm{pH}$ $4.5,2.04 \%(\mathrm{v} / \mathrm{v})$ yeast, and $36.94{ }^{\circ} \mathrm{C}$, to produce $0.281 \mathrm{~g} / \mathrm{g}$ bioethanol. With separate hydrolysis and fermentation (SHF) at optimal conditions, $0.584 \mathrm{~g} / \mathrm{g}$ reducing sugars and $0.258 \mathrm{~g} / \mathrm{g}$ bioethanol, are produced. The acid-alkali pretreatment therefore could achieve high delignification of the lignocellulosic biomass, and increase the cellulose yield, with the SSF achieving faster processing time and higher bioethanol production (Sukhang et al. 2020). The production of bioethanol as a part of palm oil processing could result in positive environmental impact in general, but may reduce the net energy ratio (NER) by $27.5 \%$, the net carbon emission ratio (NCER) by $66.6 \%$, and the carbon emission savings (CES) by $21.9 \%$. This suggests that a higher amount of energy input and GHG emissions is needed for bioethanol production, than the amount of energy it will provide and the GHG from the fossil fuels it will displace (Lim et al. 2011).

\section{Biohythane}

The biogas produced from the biological decomposition of biomass or agricultural residues, in anaerobic conditions, can be an economically and reliable source of renewable energy. The microbial bioreactions to generate biogas include acidogenesis, hydrolysis, methanogenesis, and acetogenesis, of biomass or effluents. The biogas constituents from anaerobic digestion typically are methane (60\%), carbon dioxide (35\%), hydrogen sulfide (3\%), hydrogen (1\%) and other gases (Wooster 2009). 
For biohydrogen production, the dark fermentation of POME, has been evaluated in the two-stage thermophilic $\left(55^{\circ} \mathrm{C}\right)$ and mesophilic $\left(37^{\circ} \mathrm{C}\right)$ anaerobic sequencing batch reactor (ASBR), with enriched mixed culture. The effluent from the thermophilic reactor contains 7.61 $\mathrm{g} / \mathrm{L}$ total carbon (TC) and $22.87 \mathrm{~g} / \mathrm{L}$ total suspended solids (TSS), which are then fed into the second mesophilic reactor. The thermophilic stage records the optimum $\mathrm{H}_{2}$ yield of $2.99 \mathrm{~mol} \mathrm{H}_{2} / \mathrm{mol}$ sugar, and $\mathrm{H}_{2}$ production rate of $8.54 \mathrm{mmol} \mathrm{H}_{2} / \mathrm{L}$.h, while the mesophilic stage registers $1.19 \mathrm{~mol} \mathrm{H}_{2} / \mathrm{mol}$ sugar and $1.47 \mathrm{mmol} \mathrm{H}_{2} /$ L.h. The overall improvement is an increase from 8.54 to $10.34 \mathrm{mmol}$ $\mathrm{H}_{2} /$ L.h (Maarof et al. 2019). The two-stage dark fermentation and microbial electrolysis under thermophilic condition has also resulted in maximum POME conversion into biohydrogen with the maximal yield of $0.236 \mathrm{~L} \mathrm{H}_{2} / \mathrm{g}$ carbon oxygen demand (COD) and 7.81 $\mathrm{L} \mathrm{H}_{2} / \mathrm{L}$ POME. day. The yield is 3 times higher than the dark fermentation alone, and the dark fermentation effluent is rich in acetate and butyrate (Khongkliang et al. 2019).

The two-stage thermophilic fermentation and mesophilic methanogenic process utilizing POME have exhibited the $\mathrm{H}_{2}$ potential of $170-200 \mathrm{~L} \mathrm{H}_{2} / \mathrm{kg}$ COD and the $\mathrm{CH}_{4}$ potential of 210-292 $\mathrm{L} \mathrm{CH}_{4} / \mathrm{kg} \mathrm{COD}$. The two-stage process in the continuous mode with 2 days Hydraulic Retention Time (HRT) for $\mathrm{H}_{2}$ reactor attains $210 \mathrm{~L} \mathrm{H}_{2} /$ $\mathrm{kg}$ COD, and 15 days HRT for $\mathrm{CH}_{4}$ reactor achieves 315 $\mathrm{L} \mathrm{CH}_{4} / \mathrm{kg}$ COD, with the total energy yield of $15.34 \mathrm{MJ} /$ $\mathrm{kg}$ COD. This is a $34 \%$ higher energy yield than the single stage $\mathrm{CH}_{4}$ reactor. The total production rate of biogas is 4.4 $\mathrm{L} / \mathrm{L}$ POME.day, comprising $51 \% \mathrm{CH}_{4}, 14 \% \mathrm{H}_{2}$ and $35 \% \mathrm{CO}_{2}$ (Mamimin et al. 2015). Utilizing the batch process of two-stage thermophilic fermentation and mesophilic methanogenic, and with 30\% POME recirculation, maximum of $4.1 \mathrm{~L} \mathrm{H}_{2} / \mathrm{L}$ POME and 16.6 $\mathrm{L} \mathrm{CH}_{4} / \mathrm{L}$ POME, are recorded. The continuous mode of operation, with and without recirculation, achieve slightly lower biogas at 3.8 and $2.2 \mathrm{~L} \mathrm{H}_{2} / \mathrm{L} \mathrm{POME}$, and 14 and $12.2 \mathrm{~L} \mathrm{CH}_{4} / \mathrm{L}$ POME, respectively. The yields of $0.135 \mathrm{~L} \mathrm{H}_{2} / \mathrm{g}$ Volatile Solids (VS) and $0.414 \mathrm{~L} \mathrm{CH}_{4} / \mathrm{g}$ VS are attained, with the biogas composed of $54.4 \% \mathrm{CH}_{4}, 13.3 \% \mathrm{H}_{2}$, and $32.2 \% \mathrm{CO}_{2}$ (Thong et al. 2016). The pilot scale of two-stage thermophilic fermentation has been operated at thermophilic condition $\left(55{ }^{\circ} \mathrm{C}\right)$, with organic loading rates (OLR) of $27.5 \mathrm{~g} \mathrm{COD} / \mathrm{L}$.day and 2 days HRT in the first stage, and OLR of $5.5 \mathrm{~g} \mathrm{COD/L.day} \mathrm{and} 10$ days HRT in the second stage. The biogas mixture of $52 \% \mathrm{CH}_{4}, 11 \% \mathrm{H}_{2}$, and $37 \%$ $\mathrm{CO}_{2}$, with the biohythane production rate of $1.93 \mathrm{~L}$ gas/L. day, are registered. The recirculation of methane mixed with POME (at the 1:1 ratio) provides control of the $\mathrm{pH}$ at 5-6.5 in the first stage. The $\mathrm{H}_{2} / \mathrm{CH}_{4}$ ratio of $0.13-0.18$ is suggested to be suitable for use as vehicle fuel (Seengenyoung et al. 2019).
The effluent rich in $\mathrm{H}_{2}$ from the decanter cake (DC) and the crude glycerol (CGL) co-digestion have been evaluated in the two-stage thermophilic $\mathrm{H}_{2}$ fermentation, and mesophilic methanogenic process for $\mathrm{CH}_{4}$ production. The single stage $\mathrm{H}_{2}$ production, using $2 \%(\mathrm{w} / \mathrm{v})$ total solid (TS) of DC and CGL, in 4 days HRT with optimally loaded 1.5\% CGL co-digestion, is $0.461 \mathrm{~L} \mathrm{H}_{2} / \mathrm{L}$ POME. day and $23 \mathrm{~L} \mathrm{H}_{2} / \mathrm{kg}$ TS. The semi-continuous mode of $\mathrm{CH}_{4}$ production, utilizing $0.75 \% \mathrm{CGL}$ effluent, achieves $0.736 \mathrm{~L} \mathrm{CH}_{4} / \mathrm{L}$ POME.day and $44 \mathrm{~L} \mathrm{CH} 4 / \mathrm{kg}$ TS. The total energy recovery is $0.056 \mathrm{kWh} / \mathrm{kg}$ TS (Kanchanasuta et al. 2017). The biohythane production utilizing co-digestion of oil palm solid waste residues with POME in two-stage thermophilic fermentation has been developed, resulting in biohythane yield of $26.5-34 \mathrm{~m}^{3} /$ ton waste, which is $67-114 \%$ increase, as compared to the POME digestion alone. The co-digestion of solid wastes with POME enhances the hydrolysis constant $\left(k_{h}\right)$ from $0.07-0.113$ to $0.12-0.223$ /day, which is 10 times higher than the single digestion. During hydrogen stage, Clostridium sp. predominates, while Methanosphaera sp. predominates the methane stage (Mamimin et al. 2019). The EFB has also been investigated as the potential sustainable source of biohydrogen production by electrolysis technique. The dried $\mathrm{EFB}$, cut into small pieces, and $\mathrm{FeCl}_{3} \cdot 6 \mathrm{H}_{2} \mathrm{O}$ as an oxidizer at different concentrations, are refluxed at 90-98 ${ }^{\circ} \mathrm{C}$ for $5 \mathrm{~h}$, in the presence of $10 \%(\mathrm{v} / \mathrm{v}) \mathrm{HCl}$ in deionized water. The filtered aliquot is further diluted to 1:10 ratio to reduce acidity, and made to undergo electrolysis using the titanium anode and stainless steel cathode, at $15 \mathrm{~V}$ direct current. The results suggest that the higher the oxidizer concentration used, the longer the time it takes to produce $\mathrm{H}_{2}$ gas using the aliquot with longer storage time. The fresh aliquot however records higher volume of $\mathrm{H}_{2}$ gas generated experimentally than that predicted theoretically (Amri et al. 2019).

Different types of microbial species and community have been identified during biohythane production, incorporating different mode of operations and configurations. Thermoanaerobacterium sp. has been found the predominant microbial community during the dark fermentation of POME (Maarof et al. 2019; Khongkliang et al. 2019) and during the $\mathrm{H}_{2}$ stage in the two-stage process with methanogenic effluent recirculation (Thong et al. 2016), and in the pilot scale of the two-stage thermophilic fermentation (Seengenyoung et al. 2019). The microbial electrolysis cell stage is dominated by Geobacter sp. and Desulfovibrio sp. (Khongkliang et al. 2019). In the two-stage thermophilic fermentation and mesophilic methanogenic process utilizing POME, the $\mathrm{H}_{2}$-producing bacteria Thermoanaerobacterium thermosaccharolyticum predominates the $\mathrm{H}_{2}$ reactor, and the acetoclastic Methanoculleus sp. is the dominant methanogen in the $\mathrm{CH}_{4}$ 
reactor (Mamimin et al. 2015). However, Methanosarcina sp. dominates the $\mathrm{CH}_{4}$ stage during the pilot scale of twostage thermophilic fermentation (Seengenyoung et al. 2019). The biohythane production utilizing co-digestion of oil palm solid waste residues with POME in two-stage thermophilic fermentation suggest that Clostridium sp. predominates during $\mathrm{H}_{2}$ stage, while Methanosphaera sp. predominates the $\mathrm{CH}_{4}$ stage (Mamimin et al. 2019).

\section{Microalgal POME treatment and bioenergy co-generation} The National Renewable Energy Laboratory (NREL) is among the pioneer in the research and development of algal biofuels (NREL 2015). As energy producers, algae are characterized by simple cellular structure, and rapid reproduction rate as compared to the terrestrial plants, allowing for multiple cultivation and harvesting period in a year. Algae can grow in saltwater or wastewater, whilst fixing carbon dioxide. The algal lipid contents may be in the range of $30-80 \%$ on the dry weight basis, with the oil yield of 10-800 times more than the conventional crops on per area basis (Chisti 2007; Abdullah and Ahmad 2016; Suganya et al. 2016). The microalgal lipids can be converted into biodiesel; carbohydrates (starch and cellulose) for bioethanol; and the residual fats, carbohydrates, and proteins in microalgal tissues can be transformed into biohythane by anaerobic digestion. The chemical, biochemical, and thermochemical conversion processes could produce syngas, butanol, jet fuel, and bio-oil, or for human nutrition, fine chemicals, medicine, cosmetics, and animal feed (Zhu 2015). One of the most effective way to produce algal biodiesel is to integrate with the waste-water treatment involving high technology for waste water remediation and biomethane or biohydrogen generation.

Algal cultures can be divided into photoautotrophic, heterotrophic, mixotrophic, and photoheterotrophic cultivation (Piasecka et al. 2020; Debowski et al. 2020). Autotrophic microalgae use light from photosynthesis to convert $\mathrm{CO}_{2}$, water and minerals, to grow and synthesize biocompounds. Heterotrophic microalgae can grow in the dark using organic compounds like carbon (such as sucrose, glucose, fructose, glycerol) as energy sources, while mixotrophic microalgae can use both photosynthesis and organic and inorganic carbon substrates. Heterotrophic cultures exhibit higher growth rates and biomass/ lipid productivity than the phototrophic and mixotrophic cultures (Debowski et al. 2020). However, bacterial contamination in heterotrophic mode may affect the biomass and lipid concentration although the extent of nitrogen and phosphorous degradation may be improved (Zhang et al. 2012). The cultivation of microalgae on waste water as a growth medium is more economical as the water and nutrients are readily available, while the high $\mathrm{CO}_{2}$ levels in the wastewater promote algal growth which releases $\mathrm{O}_{2}$ for the bacterial community in the waste water to further enhance the pollutant degradation rate (Wang et al. 2008; Molazadeh et al. 2019). Algae therefore play the dual role of taking up the nutrients and supplying oxygen to bacteria. The bacteria in turn participate in the breakdown of the organic matter in the waste-water, the same process as used in activated sludge. However, microalgae are able to decrease the COD and Biological Oxygen Demand (BOD) in waste-water to get rid of pathogens, nitrogen, and phosphorus, in a more economical way than the activated sludge (Singh and Dhar 2011). In highrate algal pond (HRAP) containing photobioreactor and intensified oxidation ponds, microalgae will provide oxygen for the bacteria, while the bacteria convert the minerals such as ammonium into nitrate, which is used as a nutrient for microalgae (Molazadeh et al. 2019). The species suitable for waste-water treatment include Scendesmus sp., Chlamydomonas reinhardtii, and Chlorella sp. Algal species such as Sargassum, Lamiaria, Ecklonia, Macrocystis, Durvillaea, Ulva, and Lessonia, readily adsorb hazardous heavy metal ions from the environment, through binding factors and proteins. (Abdullah and Ahmad 2016). Integrated processes of algal cultivation and waste-water treatment for biomethane production can decrease the cost associated with the $\mathrm{CO}_{2}$ biological mitigation. One of the main challenges in algal application for the waste treatment is to define a method that allows for a proper post-treatment for the biofuels production and other bioproducts (Christenson and Sims 2011).

Algal co-cultivation can be implemented to attain sustainable energy management in the palm oil mill for bioenergy co-generation, with environmental remediation and biochemicals production (Sawaengsak et al. 2014; Abdullah et al. 2015; 2016a; 2017a, b). The bioreactor configurations utilized for anaerobic decomposition of POME include up-flow anaerobic sludge blanket reactor (UASB), expanded granular sludge bed reactor (EGSB), anaerobic baffled bioreactor (ABR), modified anaerobic baffled bioreactor (MABB), up-flow anaerobic sludge fixed-film reactor (UASFF), continuous stirred tank reactor (CSTR), membrane anaerobic system (MAS), ultrasonicated membrane anaerobic system (UMAS), and ultrasonic-assisted membrane anaerobic system (UAMAS) (Abdullah and Ahmad 2016; Ohimain and Izah 2017). The EFB and palm-kernel can be used as the co-substrate to the sludge inoculum and POME to achieve high biogas production rate of $0.0574 \mathrm{~m}^{3} / \mathrm{kg}$ COD.day, and $25.6 \%$ methane, at $47.8{ }^{\circ} \mathrm{C}$, in a $500 \mathrm{~mL}$ reaction vessel (Saleh et al. 2012). The residual biomass of Chlorella from anaerobic solid-state fermentation has been pre-treated with acid, thermal and acid-thermal 
methods and the hydrolysates produced are used in the dark fermentation for hydrogen production, followed by methanogenesis during anaerobic digestion to produce biomethane. The acid-thermal pretreatment method produces a maximum content of $28.9 \mathrm{mg}$ reducing sugar $/ \mathrm{g}$ biomass, resulting in the highest hydrogen of 12.5 $\mathrm{mL} / \mathrm{g}$ Volatile Solid (VS), and biomethane of $81 \mathrm{~mL} / \mathrm{g}$ VS. The estimated total energy yield is $3.03 \mathrm{~kJ} / \mathrm{g}$ VS or $4.6 \%$ energy recovery, based on the heating value of the residual biomass (Lunprom et al. 2019). Mono-algal codigestion of Chlorella sp. at $0.12 \mathrm{~g} / \mathrm{mL}$ EFB and POME of $2 \mathrm{~mL} / \mathrm{mL}$ attains the highest biomethane rate of 5.29 $\mathrm{L} \mathrm{CH}_{4} / \mathrm{L}$ POME.day, with high removal of COD (98\%), BOD (95\%), total nitrogen (TN) (78\%) and, total organic carbon (TOC) (78\%) after 7 days of anaerobic treatment (Ahmad et al. 2014). The co-cultivation of $N$. oculata at $2 \mathrm{~mL} / \mathrm{mL}$ POME and EFB of $0.12 \mathrm{~g} / \mathrm{mL}$ POME achieves 4.61-5.02 $\mathrm{L} \mathrm{CH}_{4} / \mathrm{L}$ POME.day, with high removal efficiencies of COD (90-97\%), BOD (84-98\%), and TOC (65-80\%) (Ahmad et al. 2015).

With multi-algal anaerobic co-cultivation of Nannochloropsis oculata and Chlorella sp., each at $1 \mathrm{~mL} /$ $\mathrm{mL}$ POME, with EFB of $0.12 \mathrm{~g} / \mathrm{mL}$ POME (Table 1), the highest biomethane (4.65 L CH$/ \mathrm{L}$ POME.day) and the specific biogas rate $\left(0.124 \mathrm{~m}^{3} / \mathrm{kg}\right.$ COD.day $)$ with $\mathrm{CO}_{2}$ (2.27 $\mathrm{L} \mathrm{CO}_{2} / \mathrm{L}$ POME.day) are obtained (Ahmad et al. 2016). Microalgal co-cultivation with POME, EFB as cosubstrate, and POME sludge as an inoculum therefore not only improves the biomethane production, but also the POME remediation. The microalgae and EFB cosubstrate addition could potentially enhance the buffering capacity of the digester (Abdullah and Ahmad 2016), and complement the role of anaerobic bacteria during the digestion process. POME is rich in organic and inorganic contents, and filtered POME can be developed as an economical alternative media with seawater for microalgal cultivation to promote cell growth, lipid and fatty acids accumulation (Table 2) (Shah et al. 2014a, b; 2016). The challenges in scaling-up the microalgal culture include attaining optimal culture conditions, mixing, and achieving effective and efficient sampling and harvesting methods. The cultivation of Pavlova lutheri at 5-300 L for example, achieve the cell growth of $9.65 \times 10^{6}$ cells $/ \mathrm{mL}$ $(0.35 \mathrm{~g} / \mathrm{L})$ in $300 \mathrm{~L}$ open-tank system, which is much less than the $12-14 \times 10^{6}$ cells $/ \mathrm{mL}(0.43-0.45 \mathrm{~g} / \mathrm{L})$ achieved in $250 \mathrm{~mL}$ reaction vessel (Shah et al. 2014a, b). The Tetraselmis suecica, $N$. oculata, P. lutheri, and Isochrysis galbana cultivation in $5 \mathrm{~L}$ photobioreactor (PBR) also achieve the highest biomass $(0.62-0.96 \mathrm{~g} / \mathrm{L})$ and lipid content (31.6-42.2\%), as compared to $0.45-0.72 \mathrm{~g} / \mathrm{L}$ biomass and 24.4-38.5\% lipid in $300 \mathrm{~L}$ open-tank (Shah and Abdullah 2018). The contents of palmitic, C16:0 (18.4\%), oleic, C18:1 (11.3\%), and pentadecanoic, C15:0 (8.16\%) acids in N. oculate; and oleic, C18:1 (13.8.3\%), palmitic, C16:0 (35.2\%), and palmitoleic, C16:1 (23.3\%) acis in $P$. lutheri, are the highest in $5 \mathrm{~L}$ PBR (Shah and Abdullah 2018). These may suggest the need to suit the mode of operation and algal cultivation for specific purpose.

\section{Cellulose extraction and modification}

Globally, cellulose is the most abundant, cost-effective, and easily available natural polymer. It is the polysaccharides in the structure making up the plant cell walls (30$50 \%$ by weight). One of the largest and most well-known applications of cellulose is in the pulp and paper production (Mussatto and Loosdrecht 2016). An environmentally friendly technique has been developed for the isolation of purely extracted cellulose (PEC) from the EFB using ultrasonic (US) and $\mathrm{H}_{2} \mathrm{O}_{2}$ at $40 \mathrm{kHz}$ and room temperature, to yield $49 \% \mathrm{PEC}$ with $91.3 \% \alpha$-cellulose content and $68.7 \%$ crystallinity. The autoclave (AUTO) technique, with the combination of $\mathrm{H}_{2} \mathrm{O}_{2}$ and formic acid and more bleaching with $\mathrm{H}_{2} \mathrm{O}_{2}$ at $80{ }^{\circ} \mathrm{C}$, yields $64 \%$ PEC with $93.7 \%$ $\alpha$-cellulose and $70 \%$ crystallinity (Nazir et al. 2013). The polypropylene (PP) composites with $25 \%$ PEC loading fabricated by injection-moulding technique, attains the tensile intensity of 26.7-27.3 Mpa, without any addition of coupling factors (Fig. 2a, b). The surface engineering of PECs with Ethylene diamine tetra acetic acid (EDTA) treatment (Fig. 2c, d) has resulted in a lower degree of substitution (0.778-0.874), but with higher metal chelating ability. The high $232.9-236.7 \mathrm{mg} / \mathrm{g} \mathrm{Pb}$ (II) sorption is attributable to the polydentate ligand (Nazir et al. 2018a, b). The Pb-loaded modified PECs also achieve high diesel desulphurization with 300-350 ppm sulphur removal, as compared to $80-110 \mathrm{ppm}$ with the modified sorbents without Pb-loading (Nazir et al. 2018a, b).

\section{Bioproducts}

Bioproducts extracted from biomass are non-toxic, biodegradable, and sustainable. The essential requirements for bio-proproducts from the biorefineries are the viability for large-scale production with higher degree of coupling between bioproducts and bioenergy co-generation. The cost of the raw materials, the cost of raw material processing, the market price of current and future bioproducts, marketability and practical use that suit the market needs (Budzianowski 2017), must be considered. The EFBs and the fibres have been used as soil conditioners or as absorbents to eliminate sulphur oxides (Sulaiman et al. 2011), turned into briquettes for solid fuels (Nasrin et al. 2008), or used in the manufactured furniture, packaging or building, electronics, and motorcar materials (Nazir et al. 2018a, b; Malaysian Palm Oil Council 2019). A novel, simple and low-cost preparation method has been developed for agro-based magnetic 
Table 1 Production of biogas from the multi-algal co-digestion with EFB, POME and sludge inoculum (Ahmad et al. 2016)

\begin{tabular}{|c|c|c|c|c|c|c|c|}
\hline \multirow{2}{*}{$\begin{array}{l}\text { Expt } \\
\text { Run }\end{array}$} & \multicolumn{4}{|c|}{ Independent variables } & \multirow{2}{*}{$\begin{array}{l}\text { Specific production of } \\
\text { biogas rate }\left(\mathrm{m}^{3} / \mathrm{kg} \text { COD/ }\right. \\
\text { day) }\end{array}$} & \multirow{2}{*}{$\begin{array}{l}\text { Biomethane (mL } \\
\mathrm{CH}_{4} / \text { L POME/day) }\end{array}$} & \multirow{2}{*}{$\begin{array}{l}\mathrm{CO}_{2}(\mathrm{~mL} \\
\mathrm{CO}_{2} / \mathrm{L} \text { POME} / \\
\text { day) }\end{array}$} \\
\hline & $\begin{array}{l}\text { N. oculata }(\mathrm{mL} / \\
\text { mL POME) }\end{array}$ & $\begin{array}{l}\text { Chlorella sp. } \\
\text { (mL/mL POME) }\end{array}$ & $\begin{array}{l}\text { T. suecica }(\mathrm{mL} / \\
\mathrm{mL} \text { POME) }\end{array}$ & $\begin{array}{l}\mathrm{EFB}(\mathrm{g} / \mathrm{mL} \\
\text { POME) }\end{array}$ & & & \\
\hline \multicolumn{8}{|c|}{ Group A } \\
\hline 28 & 0 & 0 & 0 & 0.12 & 0.125 & 3539.0 & 3534.0 \\
\hline 6 & 1 & 1 & 0 & 0.12 & 0.124 & 4651.9 & 2265.9 \\
\hline 3 & 1 & 0 & 1 & 0.12 & 0.101 & 2765.2 & 2036.6 \\
\hline 22 & 0 & 1 & 1 & 0.12 & 0.104 & 3541.6 & 1556.5 \\
\hline \multicolumn{8}{|c|}{ Group B } \\
\hline 17 & 1 & 0 & 0 & 0.06 & 0.095 & 3030.6 & 1730.0 \\
\hline 10 & 0 & 1 & 0 & 0.06 & 0.121 & 3165.0 & 1883.4 \\
\hline 8 & 0 & 0 & 1 & 0.06 & 0.099 & 2853.6 & 1550.6 \\
\hline 23 & 1 & 1 & 1 & 0.06 & 0.108 & 3132.2 & 1853.6 \\
\hline 9 & 1 & 1 & 1 & 0.06 & 0.111 & 3072.2 & 2272.0 \\
\hline \multicolumn{8}{|c|}{ Group C } \\
\hline 27 & 0 & 0 & 0 & 0 & 0.104 & 2540.0 & 2532.0 \\
\hline 7 & 1 & 1 & 0 & 0 & 0.099 & 2579.8 & 2301.5 \\
\hline 13 & 1 & 0 & 1 & 0 & 0.099 & 2778.9 & 1475.1 \\
\hline 19 & 0 & 1 & 1 & 0 & 0.099 & 2353.0 & 1939.8 \\
\hline \multicolumn{8}{|c|}{ Group D } \\
\hline 18 & 2 & 1 & 1 & 0.12 & 0.097 & 4018.9 & 2079.5 \\
\hline 2 & 1 & 2 & 1 & 0.12 & 0.099 & 2787.5 & 2272.4 \\
\hline 26 & 1 & 1 & 2 & 0.12 & 0.108 & 1064.8 & 914.38 \\
\hline \multicolumn{8}{|c|}{ Group E } \\
\hline 24 & 2 & 1 & 0 & 0.06 & 0.124 & 1224.8 & 873.7 \\
\hline 14 & 2 & 0 & 1 & 0.06 & 0.121 & 2123.6 & 1643.4 \\
\hline 1 & 0 & 2 & 1 & 0.06 & 0.104 & 2224.8 & 1654.3 \\
\hline 15 & 1 & 2 & 0 & 0.06 & 0.107 & 2787.5 & 1753.9 \\
\hline 5 & 1 & 0 & 2 & 0.06 & 0.106 & 1229.4 & 1153.9 \\
\hline 16 & 0 & 1 & 2 & 0.06 & 0.089 & 1026.7 & 934.6 \\
\hline \multicolumn{8}{|c|}{ Group F } \\
\hline 12 & 2 & 2 & 1 & 0.06 & 0.077 & 952.74 & 864.8 \\
\hline 11 & 2 & 1 & 2 & 0.06 & 0.081 & 943.74 & 853.8 \\
\hline 21 & 1 & 2 & 2 & 0.06 & 0.082 & 952.74 & 863.8 \\
\hline \multicolumn{8}{|c|}{ Group G } \\
\hline 4 & 2 & 1 & 1 & 0 & 0.108 & 3601.3 & 1543.3 \\
\hline 20 & 1 & 2 & 1 & 0 & 0.096 & 2424.0 & 1984.9 \\
\hline 25 & 1 & 1 & 2 & 0 & 0.088 & 870.5 & 803.4 \\
\hline
\end{tabular}

biosorbents based on the EFBs, Ceiba pentandra, and celluloses extracted from the EFBs to attain $\mathrm{Pb}$ (II) removal efficiencies of $97.7-99.4 \%$ from the aqueous system. The magnetic biosorbents can be reused 5 times for adsorption/desorption cycles with almost consistent high performance (Daneshfozoun et al. 2017). The fabrication of a novel oil palm-based cellulose-hydroxyapatite carbon composite electrode has successfully detected trace $\mathrm{Pb}(\mathrm{II})$ ions detection with the $0.095 \pm 0.32 \mathrm{ppb}$ limit of detection (LOD) and $0.32 \pm 0.32 \mathrm{ppb}$ limit of quantification
(LOQ) in aqueous system (Ajab et al. 2020), which is comparable to $0.11 \pm 0.36 \mathrm{ppb}$ LOD and $0.36 \pm 0.36 \mathrm{ppb}$ LOQ, in blood serum (Fig. 3a) (Ajab et al. 2018), and $0.11 \pm 0.37 \mathrm{ppb}$ LOD and $0.37 \pm 0.37 \mathrm{ppb}$ LOQ, in POME (Fig. 3b) (Ajab et al. 2019).

\section{Biopharmaceuticals Biocompounds}

Biocompounds are the low volume but high-value products of a biorefinery. Table 3 shows different microalgal 
Table 2 Fatty acids profile of N. oculata and T. suecica cultured in 10\% POME in seawater (Shah et al. 2016)

\begin{tabular}{llll}
\hline Fatty acids (\%) & & N. oculata & T. suecica \\
\hline \multicolumn{2}{l}{ Saturated fatty acid } & & \\
C12:0 & Lauric acid & 0.64 & 0.52 \\
C14:0 & Tetradecanoic acid & 5.43 & 6.94 \\
C15:0 & Pentadecanoic acid & 8.45 & 9.21 \\
C16:0 & Palmitic acid & 28.22 & 36.48 \\
C17:0 & Heptadecanoic acid & 2.31 & 3.62 \\
C18:0 & Stearic acid & 7.44 & 8.33 \\
C20:0 & Eicosanoic acid & 6.75 & 3.64 \\
Total SFA & & 59.24 & 68.74 \\
Monounsaturated fatty acid & & \\
C16:1 & Palmitoleic acid & 9.37 & 5.81 \\
C18:1 & Oleic acid & 5.77 & 6.45 \\
Total MUFA & & 15.14 & 12.26 \\
Polyunsaturated fatty acid & & \\
C18:2 & Linoleic acid & 2.81 & 3.77 \\
C18:3 & Linolenic & 4.56 & 5.11 \\
C20:5 & Eicosapentaenoic acid (EPA) & 0.17 & ND \\
C22:6 & Docosahexaenoic acid (DHA) & 1.53 & ND \\
Total PUFA & & 9.07 & 8.88 \\
\hline
\end{tabular}

${ }^{\mathrm{a} N D}$, not detected bioactive compounds which confer pharmacological and chemical novelty and bioactivities (El Gamal 2010). The secondary metabolites, though contribute only a fraction of the whole biomass, are involved in the basic machinery of life such as reproduction, growth, defence and the interaction with the surrounding environment, and therefore are vital for survival (Ianora et al. 2006; Cabrita et al. 2010). The major biocompounds such as lipids and fatty acids, carbohydrates and polysaccharides, proteins and enzymes, phenolics, carotenoids, vitamins and minerals, have exhibited different bioactivities.

\section{Lipids and fatty acids}

Glycoglycerolipids such as digalactosyl diacylglycerol (DGDG), sulfoquinovosyl diacylglycerol (SQDG), and monogalactosyl diacylglycerol (MGDG) can be produced by microalgae. These lipids have significant bioactivities including in the prevention of tumour-promoting activities (Matsumoto et al. 2000), and anti-inflammation and immuno-suppressive activities (Bruno et al. 2005). Green algae have a varied range of $\mathrm{C} 16$ and $\mathrm{C} 18$ (unsaturated and saturated) fatty acids, and several species, although generally rare, have high amount of eicosapentaenoic acid (C20:5 n-3) fatty acid constituents. Chlorophyceae contains a mixture of fatty acids, similar to those found
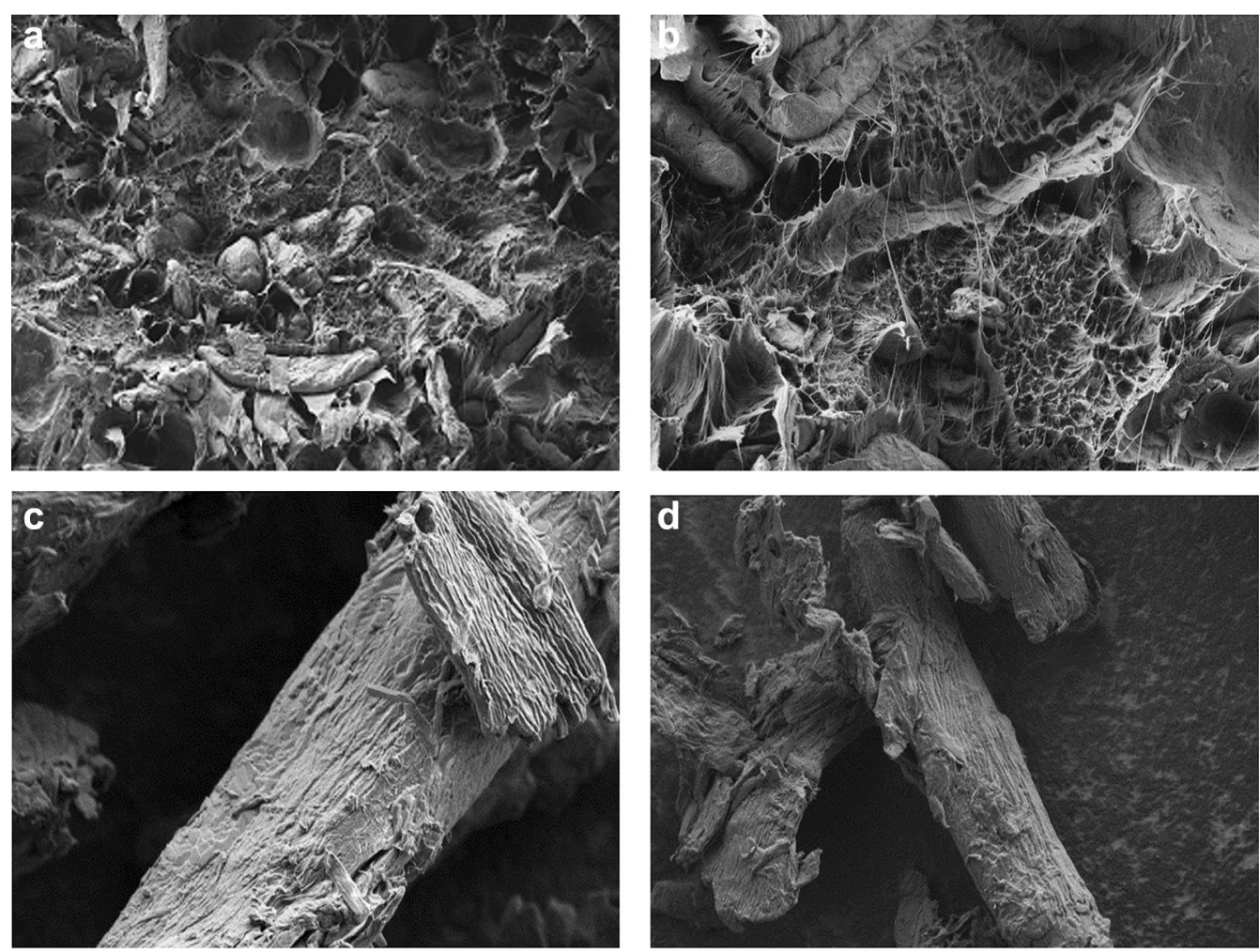

Fig. 2 SEM of a 25\% US-PEC/PP, b 25\% AUTO-PEC/PP (reproduced from Abdullah et al. 2016b, with permission from Elsevier), c US-PEC-EDTA modified, d AUTO-PEC-EDTA modified (reproduced from Nazir et al. 2018a, b) 

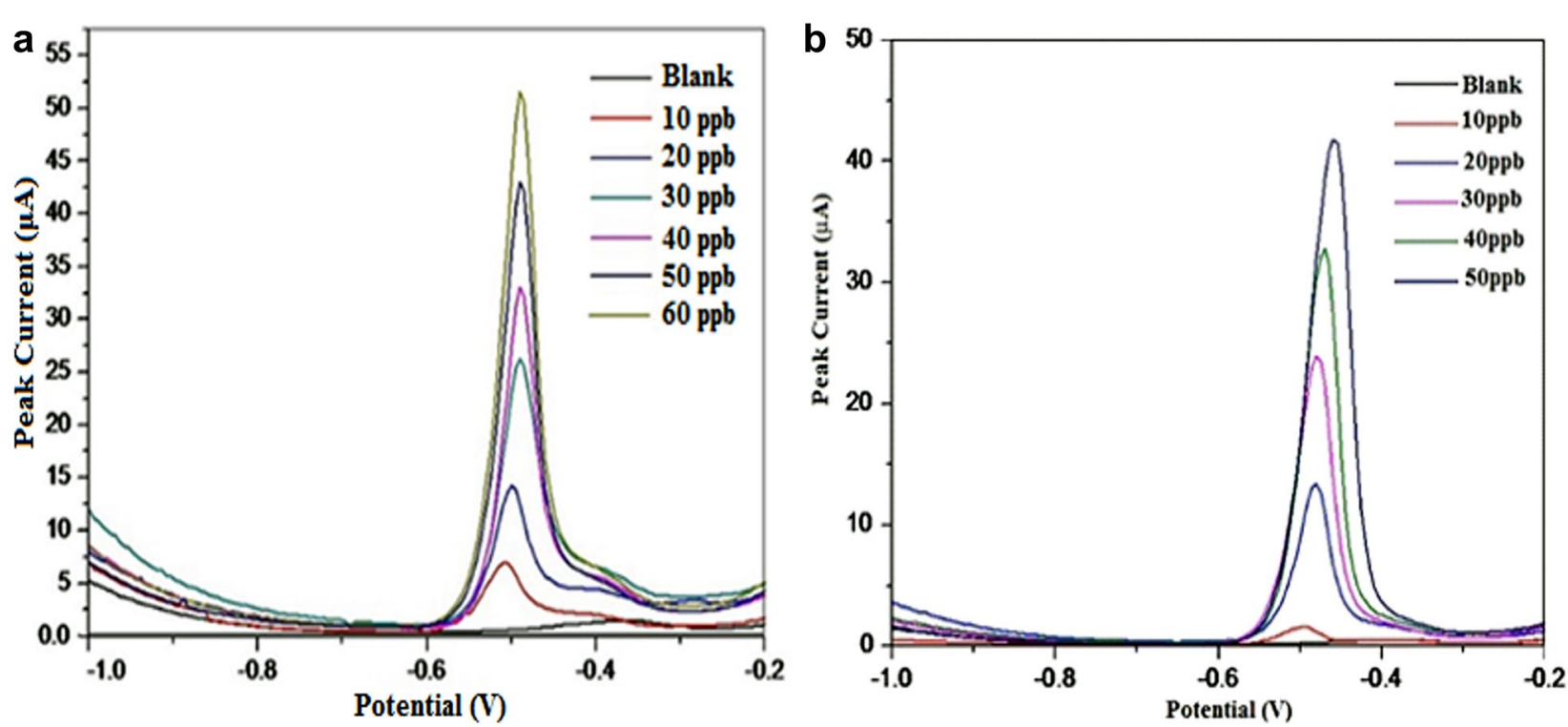

Fig. 3 Cellulose-HAp-CME stripping voltammograms for $\mathrm{Pb}$ (II) ion detection in a digested blood serum (reproduced from Ajab et al. 2018, with permission from Elsevier), b digested POME (reproduced from Ajab et al. 2019, with permission from Elsevier)

in the upper plants and oleaginous yeast. The active substance steaoryl-CoA in Chlorophyceae has resulted in a high level of $\mathrm{C} 18$ unsaturated fatty acids (Behrens and Kyle 1996). The polyunsaturated fatty acids (PUFAs) production from marine and freshwater algae has attracted attention (Wen and Chen 2003; Sijtsma and De Swaaf 2004) as the constituents such as eicosapentaenoic (EPA) and docosahexaenoic (DHA), naturally found in marine food chains, could be major therapeutic agents as antiinflammation factors, and to tackle the incidence of cardiovascular disease and arthrosclerosis in humans (Moheimani and Borowitzka 2006). The omega-3 ( $\omega-3)$ and omega- $6(\omega-6)$ fatty acids are essential for tissue regeneration and these fatty acids cannot be manufactured. Both DHA and EPA could reduce the triglycerides and increase the high density lipoprotein (HDL) levels. Since the breast milk contains high amount of DHA and EPA, the newborns are also fed with the manufactured milk containing the $\omega-3$ DHA as supplement (Guedes et al. 2011). Arachidonic acid (ARA), which belongs to the $\omega-6$ PUFA, is important as a source of diet for the general good health of pregnant woman, newborns children and elderly people. In plants, ARA can be produced from linoleic acid, and linoleic acid in turn is synthesized from oleic acid (Tallima and El Ridi 2018). Thus, it is pertinent to promote oleic acid production as an essential microalgal fatty acid constituent. PUFAs also exhibit a defensive role against free radicals affecting the skin (Natrah et al. 2007). Another interesting group of lipids from macro and microalgae is sterol (Volkman
2005; Cardozo et al. 2007). Phyto-sterols extracted from microalgae have applications in production of therapeutic steroids, cosmetics, as functional foods for anti-cancer and anti-cholesterol activities (Volkman 2005; Francavilla et al. 2012).

\section{Carbohydrates and polysaccharides}

Carbohydrate makes up 75\% of the global biomass constituent. The sugar units could be used to store energy and other important functions in living organisms (Appelt et al. 2013). Polysaccharides are high value-added ingredients in cosmetics, foodstuffs, stabilizers, cloth, medicine, and emulsions (Arad and Levy-ontman 2010). The use of microalgal polysaccharides in the pharmaceutical industry is attributable to the ease of the compound isolation (Bhattacharjee 2016). Several natural or slightly pure polysaccharides extracted from different green, red, and brown algae have been studied for their anti-tumour properties (Ramberg et al. 2010), anti-bacterial, antioxidative, anti-inflammatory, and antiviral activities (Michalak and Chojnacka 2015). The major component in $I$. galbana and $N$. oculata polysaccharide extracts include glucose at 56.9 and $68.3 \%$, respectively, while the second major compound is mannitol (38.8\%) in I. galbana, and inositol (20.32\%) in N. oculata (Hafsa et al. 2017). Nitrate concentration in the medium could affect starch accumulation in microalgae including T. suecica which is rich in intracellular polysaccharide (Kermanshahi-pour et al. 2014). Sulphate esters or sulphated polysaccharides from C. vulgaris, Scenedesmus quadricauda, and 
Table 3 Microalgal bioactive compounds and the bioactivities

\begin{tabular}{|c|c|c|c|}
\hline Compound & Source & Activity & References \\
\hline $\begin{array}{l}\text { 1. Carotenoids } \\
\beta \text {-Carotene }\end{array}$ & Dunaliella salina & $\begin{array}{l}\text { Anticancer } \\
\text { Anti-inflammatory } \\
\text { Pro-vitamin A } \\
\text { Antioxidant }\end{array}$ & (Ramos et al. 2011) \\
\hline Astaxanthin & $\begin{array}{l}\text { Haematococcus pluvialis } \\
\text { Chlorella zofigiensis }\end{array}$ & $\begin{array}{l}\text { Antioxidant } \\
\text { Anti-inflammatory } \\
\text { Anti-cancer }\end{array}$ & (Yuan et al. 2011; Liu et al. 2014) \\
\hline Lutein & $\begin{array}{l}\text { Haematococcus pluvialis } \\
\text { Chlorella protothecoides } \\
\text { Chlorella pyrenoidosa }\end{array}$ & $\begin{array}{l}\text { Antioxidant } \\
\text { Anti-inflammatory } \\
\text { Anti-cancer }\end{array}$ & (De Morais et al. 2015; Cordero et al. 2011) \\
\hline Violaxanthin & $\begin{array}{l}\text { Dunaliella tertiolecta } \\
\text { Chlorella ellipsoidea }\end{array}$ & $\begin{array}{l}\text { Anti-inflammatory } \\
\text { Anti-cancer }\end{array}$ & $\begin{array}{l}\text { (Pasquet et al. 2011; Soontornchaiboon et al. 2012; Amaro et al. } \\
2013\end{array}$ \\
\hline Zeaxanthin & $\begin{array}{l}\text { Chlorella Saccharophila } \\
\text { Chlorella ellipsoidea }\end{array}$ & $\begin{array}{l}\text { Antioxidant } \\
\text { Anti-inflammatory } \\
\text { Antiproliferation }\end{array}$ & (Amaro et al. 2013; Singh et al. 2013) \\
\hline Fucoxanthin & $\begin{array}{l}\text { Isochrysis sp. } \\
\text { Odontella aurita } \\
\text { Chaetoseros sp. }\end{array}$ & Anticancer & (Amaro et al. 2013; Crupi et al. 2013) \\
\hline \multicolumn{4}{|l|}{ 2. Fatty acids } \\
\hline Eicosapentaenoic acid (EPA) & $\begin{array}{l}\text { Tetraselmis sp. } \\
\text { Chlorella minutissima }\end{array}$ & $\begin{array}{l}\text { Anti-inflammatory } \\
\text { Anti-angiogenic }\end{array}$ & (Singh and Dhar 2011; Adarme-Vega et al. 2014) \\
\hline Docosahexaenic acid (DHA) & Tetraselmis sp. & Anti-inflammatory & (Talero et al. 2015) \\
\hline Docosapentaenoic acid (DPA) & Nannochloropsis oculata & Anti-inflammatory & (Talero et al. 2015) \\
\hline Oleic acid & $\begin{array}{l}\text { Himanthalia elongate } \\
\text { Nannochloropsis oculata } \\
\text { Chlorella vulgaris }\end{array}$ & $\begin{array}{l}\text { Antimicrobial activity } \\
\text { Antioxidant }\end{array}$ & (Plaza et al. 2010; Rajendran et al. 2014; Adhoni et al. 2016) \\
\hline Linoleic acid & $\begin{array}{l}\text { Chlorella vulgaris } \\
\text { Nostoc }\end{array}$ & $\begin{array}{l}\text { Antimicrobial activity } \\
\text { Anti-cancer } \\
\text { Antioxidant } \\
\text { Anti-inflammatory }\end{array}$ & (Adhoni et al. 2016; Bhattacharjee 2016) \\
\hline Palmitic acid & $\begin{array}{l}\text { Himanthalia elongate } \\
\text { Spirulina platensis } \\
\text { Tetraselmis sp. } \\
\text { Dunaliella sp. } \\
\text { Chlorella sp. }\end{array}$ & $\begin{array}{l}\text { Antimicrobial activity } \\
\text { Anti-oxidant }\end{array}$ & (Plaza et al. 2010; Rajendran et al. 2014 \\
\hline
\end{tabular}

Porphyridium sp. (De Morais et al. 2015), could prevent viral infections such as encephalitis virus, herpes simplex virus 1 and 2 (HSV1, HSV2), haemorrhagic septicemia in salmonid virus, HIV, and swine fever virus (Smelcerovic et al. 2008; Amaro et al. 2011). The biological activities of sulphur polysaccharides is related to the formation of sugar, and the location and the degree of sulphurization (Kim et al. 2012). The polysaccharide GA3P (D-galactan sulphate, which is related to L- $(+)$-lactic acid), produced extracellularly by the toxic dinoflagellate Gymnodinium sp. A3, is a strong inhibitor of DNA topo I and topo II, whether or not there is the presence of lactate group (Umemura et al. 2003). It also inhibits colon cancer cell lines including HCC2998, KM-12, HCT-116, HCT-15, WiDr, and HT-29 (Talero et al. 2015).

\section{Proteins and amino acids}

Different species exhibit different protein levels. The aqueous extracts of $N$. oculata, for instance, show higher protein level at $21.0 \pm 0.2 \%$ as compared to $I$. galbana at $5.2 \pm 0.17 \%$ (Hafsa et al. 2017). The normal $\mathrm{C} / \mathrm{N}$ ratio of fresh water microalgae is 10.2 , and a lower $\mathrm{C} / \mathrm{N}$ ratio in some microalgal species, as compared to the terrestrial plants, could lead to a higher protein composition (Yen and Brune 2007). Nitrogen deficiency could increase the carbohydrate content by fourfold in Tetraselmis subcordiformis (Minhas et al. 2016). The intermediates of the carbohydrate metabolism such as pyruvate, a major precursor in aerobic glycolysis, in turn, could be used for the synthesis of amino acids such as leucine (Leu), alanine (Ala), and valine (Val). On the other hand, low carbohydrate content with significant amino acids such as Leu, Ala, Val, glutamate (Glu), and isoleucine (Ile), have been reported in $C$. vulgaris exposed to high $\mathrm{CuCl}_{2}$ concentrations (Zhang et al. 2014). Proteins from marine resources have unique characteristics such as the film and foaming 
ability, gel formation capacity and anti-microbial activity (Rasmussen and Morrissey 2007). T. suecica which contains large quantity and high quality intracellular protein content, is currently produced as aquaculture feed (Kermanshahi-pour et al. 2014). Arthrospira and Chlorella sp. which are rich in protein and amino acids are advantageous for use as dietary nutrients or as functional foods to inhibit tissue damage and diseases (Santhosh et al. 2016). The phycobiliproteins from red algae and cyanobacteria such as Porphyridium sp. and Spirulina platensis, have shown anti-inflammatory, hepatoprotective, immune, anti-oxidant and anticancer activities (Romay,Gonzalez,Ledon,Remirez,a nd Rimbau 2003; Zheng et al. 2011). The phycobiliprotein C-phycocyanin produced by Spirulina platensis induces the release of cytochrome $C$ from mitochondria and triggers caspase-dependant apoptosis in HeLa cell lines (Li et al. 2006). The C-phycocyanin-mediated mitochondrial-dependant cell death has also been exhibited in the dimethylhydrazine (DMH)-induced colon cancer in the rat model (Saini et al. 2012).

\section{Phenolic compounds}

Phenolic compounds such as flavonoids have nutraceutical properties, and lignans can be of great benefits in health and care products (Metsämuuronen and Sirén 2019). Polyphenols act as antioxidants during the transfer of single electron and during the transport of hydrogen atom (Goiris et al. 2012a). Many phenolics such as flavonoids, isoflavones, dihydrochalcones and flavonols are found in microalgae (Jahnke 1999; Natrah et al. 2007). Several phenolic compounds show anti-melanoma or anti-skin cancer activities (Talero et al. 2015), and antivirals, anti-carcinogenic, antimicrobials, anti-inflammatory or anti-tumour activities (El-Baky et al. 2009; Namvar et al. 2014). Phenols are important in the formation of anti-microbial compounds like cresol and ditol (Aiyegoro and Okoh 2010). High anti-microbial activities have been exhibited by the N. gaditana, Tetraselmis sp. and Phaeodactylum tricornutum ethanol extracts, attributable to the high amount of polyphenols at 32, 25.5 and $16.8 \mathrm{mg}$ per gallic acid equivalent (GAE)/g biomass, respectively (Maadane et al. 2017). High phenolic content (>3 mg GAE/g biomass) has been reported in the ethanol/water extracts of Isochrysis, Phaeodactylum and Tetraselmis sp. (Goiris et al. 2012b). Chlorella, which contains large amount of phenolics content, similar to the level in other plant sources, also exhibits high antioxidant activity at $58.73 \mathrm{mg} \mathrm{GAE} / \mathrm{g}$ (Zakaria et al. 2017).

\section{Vitamins and minerals}

Microalgae are important sources of essential vitamins such as tocopherol, ascorbic acid, B1, B2, B6, B12, nicotinic acid, and biotin; in addition to macro-minerals $(\mathrm{K}, \mathrm{Na}, \mathrm{Mg}, \mathrm{Ca})$ and micro-minerals $(\mathrm{Zn}, \mathrm{Fe}, \mathrm{Mn}$, $\mathrm{Cu})$ (Christaki et al. 2011). Vitamins such as $\beta$-carotene (pro-vitamin A), tocopherol, folic acid and thiamine are found in higher concentrations in some marine algae as compared to the other traditional foods considered as rich sources of these vitamins. Dunaliella tertiolecta and Chlorella stigrnatophora exhibit the highest concentrations of vitamin A, while T. suecica and D. tertiolecta for thiamin (Fabregas and Herrero 1990). Besides synthesizing $\beta$-carotene, $D$. salina also synthesizes pyridoxine, thiamine, nicotinic acid, tocopherol, biotin and riboflavin (Santhosh et al. 2016). Spirulina and Chlorella are rich with vitamins B complex, particularly B12, that is essential for the production and renewal of blood cells (De Morais et al. 2015). Diatom Haslea ostrearia (Navicula) is especially rich in vitamin E, while Porphyridium cruentum is rich with vitamins $\mathrm{C}, \mathrm{E}$ (tocopherols) and $\beta$-carotene. T. suecica and $D$. tertiolecta cultured under nitrogen deficiency conditions have been found to have the vitamin E production increased (Sathasivam et al. 2019). The production of bio-based vitamins within the biorefineries setting can be linked to the bioenergies cogeneration. The production of vitamin B2 by the fermentation of vegetable oil with the microbes, for example, has been coupled to the anaerobic digestion of the residual biomass for biomethane generation (Budzianowski 2017).

\section{Carotenoids}

In photosynthetic organisms such as plants and algae, carotenoids act as pigments for light-harvesting and protecting the photosynthetic machinery from excessive light and oxidative stress by scavenging the reactive oxygen species (ROS), singlet oxygen, and free radicals (Deeming-Adams and Adams 2002; Kelly and Strasser 2011; Skibsted 2012). The carotenoids consist of xanthophylls (containing oxygen) and the carotenes (pure hydrocarbons with no oxygen) and contribute significantly in the overall anti-oxidant activities of algae (Takaichi 2011; Goiris et al. 2012b). The xanthophylls produced by higher plants or green microalgae include antheraxanthin, violaxanthin, neoxanthin, zeaxanthin, and lutein. However, microalgae contain more xanthophylls such as astaxanthin, canthaxanthin, and loroxanthin, while both algae and diatoms can synthesize diadinoxanthin, fucoxanthin, and diatoxanthin (Barredo 2012). Carotenoids could stimulate the immune system and reduce the incidence of chronic diseases such as cancer, heart disease, arthritis, and early aging (Mojaat et al. 2008). Although synthetic carotenoids can be cheaper, there is a need to consider natural carotenoids as the latter may have less concern with regards to their biological functions and food safety for human consumption ( $\mathrm{Li}$ 
et al. 2011). When compared to the synthetic type, the purified $\beta$-carotene from $D$. salina could induce apoptosis in the prostate cell lines (Jayappriyan et al. 2013). The asbestos workers or smokers administered with the synthetic $\beta$-carotene have been reported to face higher risk of getting cancer or cardiovascular problems (Omenn et al. 1996). Several species such as Chlorella sp., $T$. suecica, Isochrysis, and Phaeodactylum sp. contain high carotenoids ( $>3 \mathrm{mg} / \mathrm{g}$ biomass) in the ethanol/water extracts, with the highest at $7.8 \mathrm{mg} / \mathrm{g}$ biomass, while the lowest $(1.65 \pm 0.10 \mathrm{mg} / \mathrm{g}$ biomass) is observed in $N$. oculata (Goiris et al. 2012b). The major carotenoids in $C$. fusca and C. vulgaris include lutein, $\beta$-cryptoxanthin and $\beta$-carotene, and the ratios are different with higher lutein is detected in C. fusca $(69.54 \pm 11.29 \mu \mathrm{g} / \mathrm{g} \mathrm{DW})$ and $\beta$-carotene $(18.42 \pm 9.2 \mu \mathrm{g} / \mathrm{g} \mathrm{DW})$ in C. vulgaris (Othman et al. 2017). Dunaliella salina has been identified as the major source of $\beta$-carotene, with over $14 \%$ of the dry biomass content (Jayappriyan et al. 2013), and astaxanthin content in Haematococcus pluvialis is reported at 1-8\% of the dry biomass (De Morais et al. 2015). Astaxanthin can be utilized as a bio-nutraceutical in salmon farming (Budzianowski 2017).

\section{Bioactivities}

\section{Anti-cancer}

Many anti-tumour agents derived from marine origin are from marine algae (Mayer and Gustafson 2008; Devi and Bhimba 2012; Monteiro et al. 2014; Sharif et al. 2014).
The antioxidant and anti-inflammatory effects, and the dietary fibres may have contributed towards the anticancer activities of the marine algae (Kannan et al. 2010; Matharasi et al. 2018). Figure 4 shows the anti-cancer mechanism/s of microalgae (El-hack et al. 2019) including in the prevention of cancer cell growth, invasion, and metastases; reduced synthesis of microtubules; antiangiogenic activity; and stimulation of programmed cell death in cancer cells (Farooqi et al. 2012; El-hack et al. 2019). The Nannochloropsis oculata extracts have shown no toxic effects on rats when administered orally, suggesting that the omega-3 oil present in the algal strain is not pathogenic (Kagana and Matulka 2015). The Chaetoceros calcitrans ethanol extracts (EEC) have shown higher anticancer activities against the breast cancer cells (MCF-7) than the normal MCF-10A cells, at the $\mathrm{IC}_{50}$ value of $3 \pm 0.65 \mu \mathrm{g} / \mathrm{mL}$ after $24 \mathrm{~h}$ treatment (Nigjeh et al. 2013). The C. sorokiniana and Scenedesmus sp. have shown anti-cancer activity against murine tumour cell line L5178Y-R but no significant effects are reported on the viability of the normal murine thymus lymphocyte (Reyna-Martinez et al. 2018). The hot water-soluble polysaccharide compounds isolated from Capsosiphon fulvescens (chlorophycean algae) have shown the ability to stimulate apoptosis in AGS gastric cell lines (Kwon and Nam 2007). The Sargassum muticum (brown seaweeds) methanolic extract (SMME) exhibits the $\mathrm{IC}_{50}$ of $55 \mu \mathrm{g} /$ $\mathrm{mL}$ and $22 \mu \mathrm{g} / \mathrm{mL}$ against MDA-MB-231 and MCF-7 cell lines, respectively (Namvar et al. 2013). The SMME can

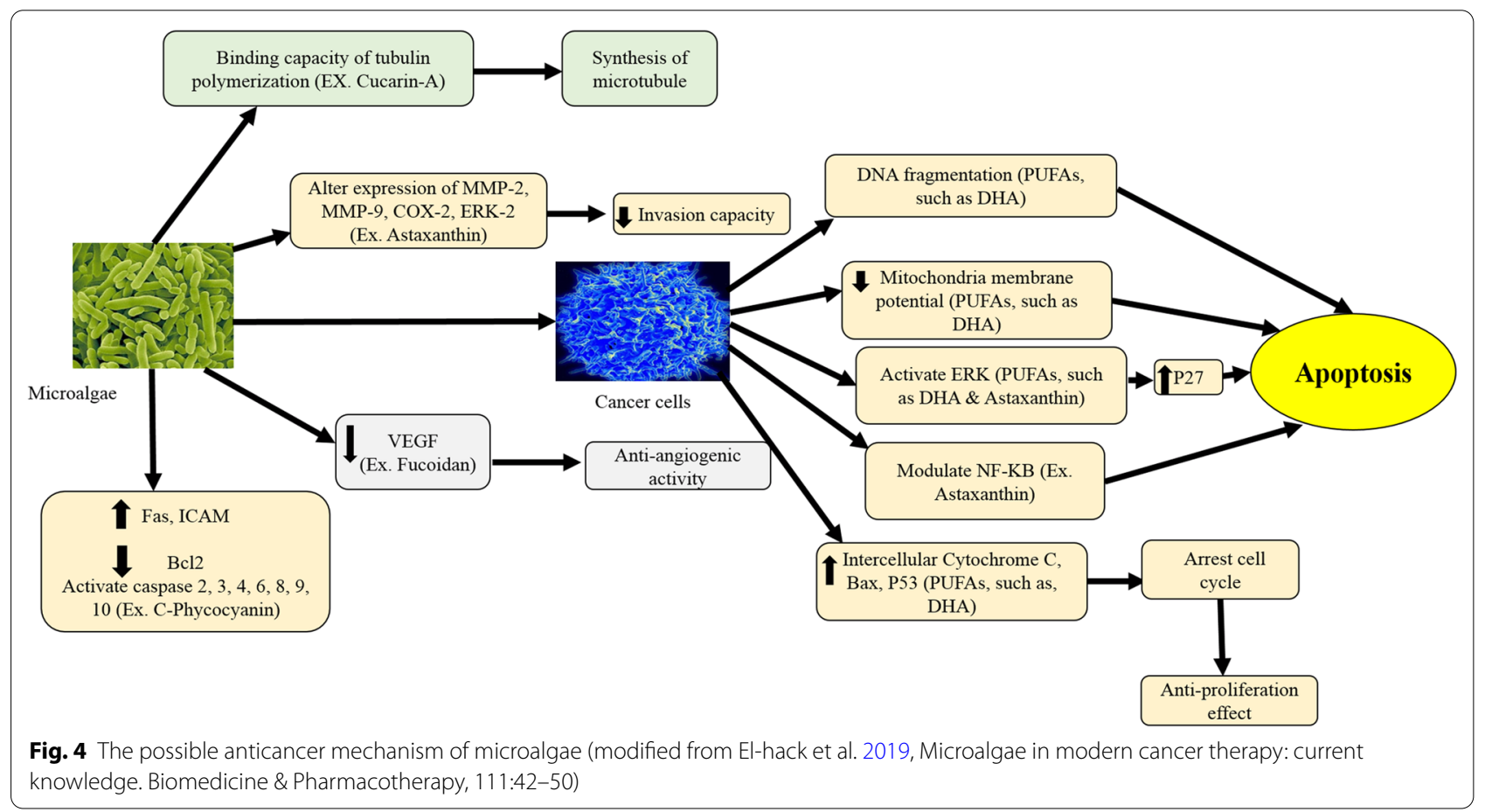


stimulate programmed cell death in human breast cancer cells whilst significantly reducing angiogenesis in chorioallantoic membrane (CAM) (Cabrita et al. 2010).

The C. vulgaris extracts have exhibited anti-cancer activity against hepatoma cell line (HepG2) at the $\mathrm{IC}_{50}$ of $1.6 \mathrm{mg} / \mathrm{mL}$ (Yusof et al. 2010; Lin et al. 2017), but the induction of apoptosis in C. ellipsoidea is 2.5 times higher than the C. vulgaris extracts (Cha et al. 2008; Lin et al. 2017). The $C$. vulgaris chloroform extracts have shown high cytotoxicity on the MCF-7 cells $\left(\mathrm{IC}_{50}\right.$ of 89 $\mu \mathrm{g} / \mathrm{mL}$ ), but the activities are lower than those exhibited by the ethanol extracts of Spirulina and Chlorella (Syahril et al. 2011). The cytotoxicity of Spirulina extracts has been attributed to the presence of carotenoids, chlorophyll, and phycocyanin, and also polysaccharides (Hernandez et al. 2017). Novel compound sargaquinoic acid isolated from $S$. heterophyllum stimulates the apoptotic pathway in the metastatic MDA-MB-231 cells $\left(\mathrm{IC}_{50}\right.$ of 67 $\mu \mathrm{M})$ (De La Mare et al. 2012). Stigmasterol isolated from Navicula incerta also exhibits strong apoptotic inductive activity with great potential to be developed as anticancer therapeutics against liver cancer (Kim et al. 2014). The fucoidan compound extracted from Fucus vesiculosus exhibits cytotoxic effect against breast cancer in vitro and in vivo (Xue et al. 2012), and the crude fucoidan has significantly reduced the $4 \mathrm{~T} 1$ cell numbers (a highly metastatic breast cancer cell line from mouse model) (Moussavou et al. 2014).

\section{Anti-oxidant}

Various bioactivities such as anti-atherosclerotic, antiinflammatory, anti-arterial and anti-carcinogenic activities can be linked to their anti-oxidant activities (Abdullah et al. 2017a). Synthetic antioxidants like butylated hydroxytoluene (BHT) or butylated hydroxyanisole (BHA) are carcinogenic (Namiki 1990; Pokorn 1991). Natural antioxidants are more appropriate for human consumption and the search for the new sources as viable alternatives to the synthetic ones has gained traction (Maadane et al. 2015). Natural antioxidants traditionally are from the plant origins, but the production from plants is expensive and time-consuming (Azim et al. 2018). Microalgae as a new source of antioxidant is attractive due to its relatively rapid growth and high content of secondary metabolites (Table 4) (Bule et al. 2018). As photosynthetic organisms, microalgae undergo continuous exposure to high oxygen concentrations and light, which stimulate the activation of free radicals and other oxidizing agents. Lack of damage to the microalgal structure suggests that their anti-oxidative mechanisms are effective for protection from the ROS and oxidative stress. Microalgae are rich in natural antioxidants such as tocopherols (Zubia et al. 2009), palmitoleic acid, linolenic
Table 4 Algal bioactive compounds (modified from Michalak and Chojnacka 2015)

\begin{tabular}{ll}
\hline Biologically active substances & Activity \\
\hline Polyphenol & Anti-tumour \\
Carotenoids & \\
Polysaccharide & Antioxidative \\
Protein & \\
Mycosporine-like amino acid & \\
Glutathione & \\
Polyphenol & \\
Polysaccharide & \\
Polyunsaturated fatty acids (PUFAs) & \\
Carotenoids & \\
Tocopherol & Anti-bacterial \\
Ascorbate & \\
Protein & \\
Polyphenol & \\
Polysaccharide & \\
Chlorophyll and carotenoids & Anti-fungal \\
PUFAs & \\
PUFAs & \\
Chlorophyll and carotenoids & \\
Terpenes & \\
Phenols & Anti-viral \\
Protein & \\
Carotenoids & \\
Polysaccharide & \\
Sterols & \\
Polyphenol & \\
Olyphenol & \\
Carotenoids & \\
Dolysaccharide & \\
Protein & \\
\hline
\end{tabular}

acid, cyanovirin, phycocyanin, oleic acid, vitamin E and B12, lutein, zeaxanthin, phlorotannins, carotenoids, ascorbic acid and $\beta$-carotene (Harun et al. 2010). The anti-oxidant defence mechanisms may also involve the antioxidant enzymes (catalase or superoxide dismutase) and the low molecular weight antioxidants (LMWA) (such as glutathione, carotenoids, phenolics, ascorbate, and tocopherol) (Goiris et al. 2012a).

The inhibition of cancer by algal extracts has been attributed to its antioxidant activities (Miranda et al. 1998). Based on $\beta$-carotene-linoleic acid bleaching method, different microalgal extracts have exhibited antioxidant activities such as Oscillatoria sp. hexane extract (97.7\%), S. platensis ethyl acetate and water extract (93.6 and 90.1\%, respectively), and S. obliquus chloroform extract $(92.4 \pm 0.3 \%)$, which are comparable to the standard synthetic antioxidant, BHT $(97.7 \pm 0.3 \%)$, but much higher than the ascorbic acid (AscA) $(25.5 \pm 0.2 \%)$ (Abdullah et al. 2017a). The DPPH (2,2-diphenyl-1-picrylhydrazyl) scavenging method exhibits low/moderate anti-oxidant activities ranging from $26.3 \pm 0.7$ to $69.1 \pm 0.4 \%$, as compared to the $85.8 \pm 0.1 \% \mathrm{BHT}$ and 
$94.6 \pm 0.1 \%$ AscA (Ali et al. 2014a). The sensitivity of the assay methods is therefore pertinent to interpret the antioxidant activities and their correlations to the metabolite contents such as the phenolics compounds (Ali et al. 2014b). The methanolic extracts of $N$. oculata exhibit the highest DPPH radical scavenging activity at $400 \mu \mathrm{g} /$ $\mathrm{mL}(21.68 \pm 1.41 \%$ inhibition $)$ as compared to the ethyl acetate extracts with $39.03 \pm 0.97 \%$ inhibition (Ebrahimzadeh et al. 2018). N. oculata extracts exhibit antioxidant activities with the $\mathrm{IC}_{50}$ values between $4.93-7.31 \%$ (Custódio et al. 2015), while the water-soluble polysaccharides extracted from $N$. oculata and I. galbana at $10 \mathrm{mg} / \mathrm{mL}$, show antioxidant activities of $59.07 \%$ and $41.45 \%$, respectively (Hafsa et al. 2017). The D. salina, Tetraselmis chuii and Isochrysis galbanaas methanolic extracts at $50 \mathrm{ppm}$, as established by the DPPH assay, suggest that the I. galbana clone Tahiti exhibits the highest activity with $61.64 \%$ of free radicals inhibition, followed by D. salina (58.45\%) and T. chuii (52.58\%) (Widowati et al. 2017). Chlamydomonas reinhardtii and C. vulgaris, respectively, show high antioxidant activity at $1000 \mu \mathrm{g} / \mathrm{mL}$ with 83.38 and $92.57 \% \mathrm{DPPH}$ free-radical scavenging activity, and 82.74 and $97.9 \%$ of the total antioxidant activity (Jayshree et al. 2016).

\section{Anti-microbial}

Due to the increased phenomenon of antibiotic-resistant bacteria globally, there is an urgent need to develop a new and potent agent against infectious diseases (Sanmukh et al. 2014). The allelopathic compounds which can be produced by some algal species such as Tetraselmis sp., have the ability to decrease the growth of the competitor and predator microorganisms (Makridis et al. 2000). The anti-microbial activity of Tetraselmis sp. extracted by methanol, diethyl ether and hexane have been studied by using agar disc diffusion method against Gram-negative bacteria (S. aureus, Bacillus subtilis, Pseudomonas aeruginosa), Gram-positive bacteria (Proteus vulgaris, E. coli) and fungal pathogens (Aspergillus niger, Aspergillus fumigatus, and C. albicans). The higher inhibition zone is achieved with the methanolic extracts against E. coli $(16 \mathrm{~mm})$ and $S$. aureus $(15 \mathrm{~mm})$, and against the fungal pathogens A. niger $(7 \mathrm{~mm})$. All Tetraselmis sp. extracts however exhibit no effects against $P$. vulgaris, A. fumigatus and C. albicans. These anti-bacterial activities are attributed to the bioactive compounds in the methanolic extracts with promising pharmaceutical applications (Matharasi et al. 2018). The methanol and chloroform extracts of 3 seagrasses, with the methanolic extracts being the most active ones, inhibit the growth of all pathogenic bacteria tested such as $S$. aureus, Vibrio cholerae, Shigella dysentriae, S. bodii, S. paratyphi, P. aeruginosa and Klebsiella pneumoniae (Kannan et al. 2010).
On the other hand, the hexane and methanolic crude extracts of N. oculata, T. suecica and Chlorella sp., in coapplication with silver nanoparticles (AgNPs), at the 1.5:1 ratios (AgNPs:Microalgal extracts $(\mathrm{w} / \mathrm{w})$ ), exhibit more consistent and stronger activities against Bacillus subtilis, Streptococcus uberis, and Salmonella sp., than the microalgal crude extracts alone. The AgNPs-T. suecicaHEX and MET, and the AgNPs-Chlorella sp.-HEX, at the 1.5:1 ratios, also exhibit strong activities against $K$. pneumonia (Hussein et al. 2020b). The antimicrobial activities, as exhibited by the extracts from the solvents of low to moderate polarity, may be related to the fatty acids contents, phenolic compounds and carotenoids. However, the extracts from the more polar ethanol solvent, of $N$. gaditana, D. Salina, Dunaliella sp., Isochrysis sp. and $P$. tricornutum, have also shown inhibitory activities against $P$. aeruginosa and Escherichia coli with a minimum inhibitory concentration (MIC) at 2.6 to $4.3 \mathrm{mg} / \mathrm{mL}$. The $N$. gaditana extracts show antimicrobial effects on Staphylococcus aureus, with the highest anti-fungal activity against Candida albicans at the MIC of $4.0 \mathrm{mg} / \mathrm{mL}$ (Maadane et al. 2017). Infact, the methanol, chloroform, diethyl ether and ethanol extracts of C. vulgaris have all shown anti-bacterial activity against the Gram-negative $\left(\mathrm{G}^{-\mathrm{ve}}\right)$ and Gram-positive $\left(\mathrm{G}^{+\mathrm{ve}}\right)$ human pathogenic bacteria (Dineshkumar et al. 2017). However, the degree of inhibition and activities may be different. For example, the effective inhibition zone of Chlamydomonas reinhardtii extracts against $\mathrm{G}^{-\mathrm{ve}}$ bacteria (P. aeruginosa, $S$. aureus, and E. coli) are higher than the C. vulgaris extracts (Jayshree et al. 2016). Hence, the methods of extraction and the solvent systems used are of great importance to ensure that the compounds with antimicrobial/allelopathic activities could be isolated and identified.

\section{Chemical profiling and analyses}

To efficiently utilize the bioproducts for its intended applications, it is pertinent to understand the diversity of organic compounds as precursors, "lubricants" or end-products in living organisms (Rojas et al. 2014). As the final products of the cellular regulatory mechanisms, the types and levels of compounds of a biosystem can be considered as the final response to any environmental or genetic perturbations (Fiehn 2002). The primary metabolites, including proteins, carbohydrates, nucleic acids, and fats, are essential and have wide classification and distributions (Hanssen 2014). Secondary metabolites, in contrast, are not dynamically produced by general metabolic pathways, have limited classification and distribution, and may be restricted to a particular species or genus (Gouvea et al. 2012; Sacristán-soriano et al. 2012). The challenge to get a snapshot of the biological 
responses in time and space is in having to analyse a huge array of metabolites and structures, and to develop optimal analytical procedures and measurements (Gomezcasati et al. 2013). The comprehensive and high quality analysis of metabolite mixtures is called metabolomics which has emerged as a useful methodology in functional genomics to understand the complex molecular interactions in biological systems (Hall et al. 2002; Gomez-casati et al. 2013). The developments have been much assisted by the advancement in the computing techniques and speed which allow the interpretation of metabolic data in relations to the metabolic pathways (Wishart 2007, 2011). With improved sensitivity and specificity of small molecule detection, identification and measurement of complex metabolic profiles in the biological specimen have led to simultaneous measurement of tens and hundreds of metabolites in a single sample (Psychogios et al. 2011; Bouatra et al. 2013). It has important applications in food technology, pharmacology, microbial biotechnology, drug and enzyme discovery, toxicology, plant biotechnology, and systems biology (Gomez-casati et al. 2013) (Additional file 1: Fig. S1). Metabolomics is a valuable tool to analyse herbal product composition, identify active metabolites and classify the specimens on the basis of different metabolites due to the environmental and genetic variations (Urso et al. 2018). In oncology, metabolomics has potential for evaluation of early cancer detection and for cancer diagnosis, prognosis and therapeutic efficacy; to predict and identify pharmacodynamics marker of any drug effects; and to provide a link between metabolic profiling and molecular imaging techniques to enable non-invasive discrimination of metabolic markers in vivo (Spratlin et al. 2009).

The development of advanced technology to separate and detect more metabolites allow aqueous and lipid-based metabolites to be evaluated simultaneously (Sas et al. 2015). The TLC/HPTLC (high-performance thin-layer chromatography) finger printing provide useful information on the marker chemical compounds and could help in the quality control and monitoring of some species (Murugesan and Bhuvaneswari 2016). The mass spectrometry (MS), often used alongside either the liquid chromatography (LC) or gas chromatography (GC), is one of the most common analytically sensitive techniques in metabolomics (Urso et al. 2018). The GC or LC separates the components of the mixture while the MS analyses each component separately and defines the structure of the compounds depending on the mass-tocharge ratio in the charged molecules (Arora and Kumar 2017). The GC-MS focuses primarily on the volatile metabolites and the derivitizable compounds with low polarity and which are more stable (Stringer et al. 2016), such as sugars, amino acids, sugar alcohols, organic acids, and polyamines. This may lead to a fairly inclusive coverage of the primary metabolites in the central pathways (Obata et al. 2013). The LC-MS could detect nanomolar concentrations, without any need for sample derivatization. The most common soft ionizer is the electrospray ionization (ESI) which is usually associated with the LCMS, and it is the best to analyse the compounds with ionic functional groups (Matich 2018). Both LC-MS and GC-MS methods complement each other (Matich 2018). Nuclear magnetic resonance (NMR) spectroscopy is ideal for primary macro-analysis at the metabolism level of the organism (Pan and Raftery 2007). Though less sensitive than the MS method, NMR is non-invasive, non-selective and with easy sample preparation steps. The metabolomics based ${ }^{1} \mathrm{H}$ NMR has been used extensively for nontargeted analysis to determine the relationship between the metabolites detected in the spectra of the biological extracts, to their bioactivities (Azizan et al. 2018). Each metabolite has a special NMR spectrum that exhibits the environment of each proton. These vibrations are further broken down by the interaction with the protons of the neighbouring carbon atoms. The area below the peak is directly proportional to the metabolite concentration, which can be measured using an appropriate internal standard such as 2,2-dimethyl-2-silapentane-5-sulfonate (DSS) (Stringer et al. 2016). The NMR coupled with the multivariate data analysis (MVDA) methods could be used to develop and obtain maximum targeted metabolites in a short time. Advances and interrelated analyses based on NMR and MS could ultimately complement each other and shift the study on the metabolism to a new paradigm (Azizan et al. 2018).

The metabolomics studies of the biological samples typically consist of five different steps (Additional file 1: Fig. S2): (1) experimental design; (2) sample preparation; (3) separation and detection of metabolites; (4) data processing; and (5) bioinformatics analysis (Sas et al. 2015). The essential component of NMR-based and MS-based studies is the suppression/extraction of the metabolites, collection of data and processing and analysis of data or the chemometric tools (Urso et al. 2018). Both NMR and MS analyses show a higher amount of chlorophyll and other polar compounds in the chloroform/methanol extracts as compared to the hexane extracts. In a smaller $(500 \mathrm{mg}$ ) solid phase extraction columns for over $50 \mathrm{mg}$ extract weights, $N$. oculata has shown higher chlorophyll contents while T. suecica shows significant PUFA as compared to the other microalgae (Danielewicz et al. 2011). The ${ }^{1} \mathrm{H}$-NMR spectroscopy of Wolfipori cocos detects 33 different chemical metabolites in $\mathrm{D}_{2} \mathrm{O}$, containing 11 organic acids, 13 amino acids, 3 sugar alcohols, 2 sugars, and 1 nucleoside. W. cocos could therefore be cultivated to extract large quantities of bioactive compounds for 


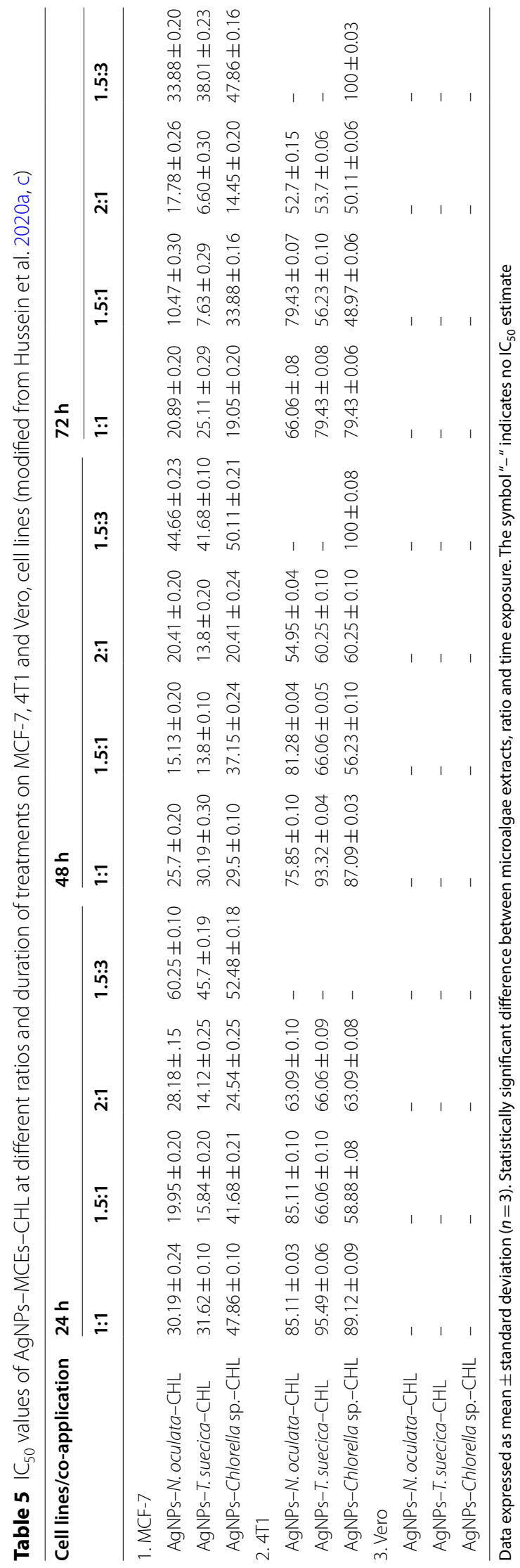


use in nutraceutical and pharmacological applications (Oh et al. 2018). The various metabolites in the Fragaria vesca extracts, most of which have already been reported in the Fragaria ananassa species, could be classified as belonging to the flavonoids, catechin, oligomirates and igitaine (Kårlund et al. 2015). The LC-MS data has been correlated to the antioxidant activity for different extract as determined by the trolox equivalent antioxidant assay (TEAC) (Urso et al. 2018). The A. kurrat methanolic extract shows higher anti-oxidant activity as well as cytotoxic activity against human colon carcinoma (Caco-2) and HepG2 based on the neutral-red test. The main components of the methanolic extract and ethyl acetate fraction, as determined by the HPLC-ESI-MS analysis, have confirmed the presence of phenolic acids and flavonoid glycosides which may contribute towards the anti-cancer activity (Abdel-Hady et al. 2018).

\section{Drug delivery and nanomedicine}

Integrating the algal biocompounds production with nanomedicine could lead to a more affordable healthcare, and revolutionize cancer therapeutics with minimal or no side-effects (Abdullah et al. 2014; Gul-e-Saba and Abdullah 2015; Hussein et al. 2020a). The microalgal crude extracts (MCEs) and bioactive compounds with metal nanoparticles such as the AgNPs, have potentials in cancer treatment and for theranostics applications. The AgNPs are medically related metallic NPs with different degrees of cytotoxicity which can target specific diseases and cancer cells and tissue (Wicki et al. 2015). High cytotoxicity on MCF-7 and 4T1 breast cancer cell lines but without any cytotoxicity on the non-cancerous Vero cells, have been shown by the co-application of AgNPsMCEs-chloroform (CHL) (Table 5) (Hussein et al. 2020a, c). The microalgal metabolites even reduce the cytotoxic effects of elevated AgNPs against the non-cancerous Vero cells whilst retaining the cytoxocity against the cancerous MCF-7 and 4T1 cells (Hussein et al. 2020d). This could open up a new avenue for the use of natural products from microalgae with nanoparticles for high-value pharmaceutical applications. As the active pharmaceutical ingredients (API) in chemotherapy can be very toxic to both normal and cancer cells, the microalgal extractdrug formulation (Hussein et al. 2020a), or liposomes as drug delivery systems (Fig. 5) (Shaheen et al. 2006), could specifically target the cancerous cells and spare the healthy cells or tissues. These may be necessary for treatment efficacy at the rate based on the needs of the body and targeted site. Liposomes consist of phosphatidylcholine-enriched phospholipids, and the mixture of the phosphorus chains with surfactant properties. The vesicle system and the bilayer vascular structures form spontaneously when phosphorus is dispersed in water, with colloidal domains of the non-active cholesterol, glycolipids, long-chain fatty acids, sphingolipids, and proteins, and the drug molecules (Tiwari 2013; Suriyakala et al. 2014). A few drugs have been formulated as lipids to improve their treatment, and liposomes can be used as carriers of anticancer and antitumor drugs, antifungal drugs, analgesic drugs, gene therapeutics and vaccines (Yadav et al. 2017; Olusanya et al. 2018). The microalgal phospholipids (PL) for the liposomes production, provide a mixture of the hydrophobic compounds and $\omega-3$ fatty acids, and can increase the DHA adsorption in infants, and reduce the cholesterol and the cirrhosis in mammalian models (Lawlor et al. 2017). The PLs extracted from Galaxoura cylindriea, Laurencia popillose, Ulva fasciata, Taonia atomaria, and Dilophys fasciola have exhibited higher anti-cancer activity against human liver and breast cancer cells in vitro at the $\mathrm{IC}_{50}$ values of 0.47 to $3.15 \mu \mathrm{g} /$ $\mathrm{mL}$, respectively. The PL of $U$. fasciata and L. popillose also show antiviral activity against simplex virus type 1 and antimicrobial activity against $B$. subtili and $E$. coli at the MIC of $40 \mu \mathrm{g} / \mathrm{mL}$ (Abd El Baky et al. 2014).

\section{Global sustainable development goals (SDGs) and life cycle analysis (LCA)}

The concept of an integrated biorefinery based on palm oil mill (Garcia-Nunez et al. 2016) and co-cultivation of microalgae (Fig. 6) (Abdullah and Hussein 2020) should meet the SDG 7 on affordable and clean energy, SDG 8 on decent work and economic growth, and SDG 9 on the industry, innovation, and infrastructure. The indirect impacts include in reducing inequality (SDG 10), developing sustainable cities and communities (SDG 11), and in practising responsible production and consumption (SDG 12) (About the Sustainable Development Goals 2019). The key performance indicators should be based on the combination of economic performance indicator, with the environmental and social impact indicators. The LCA-based environmental impact assessment is performed with eco-efficiency analysis to evaluate the trade-offs between economic output, environmental impacts (such as pesticides, fertilizer use, field emissions, field operations or irrigation) and resource utilization (energy, water, land or materials) (Begum and Saad 2013; $\mathrm{Ng}$ and Ng 2013; Ng et al. 2013, 2015), and the associated problems in relation to the quality of air, water and soil; management of wastes and waste water; GHG emission; maintenance and preservation of biodiversity and wildlife; and energy efficiency (Pérez et al. 2017). The scope and goal of an LCA are the two essential stages in which the system boundaries and the system definition depend on. The goal will determine the design, operation, and policy to be formulated and executed. For effective design and operation, the system definition must address 


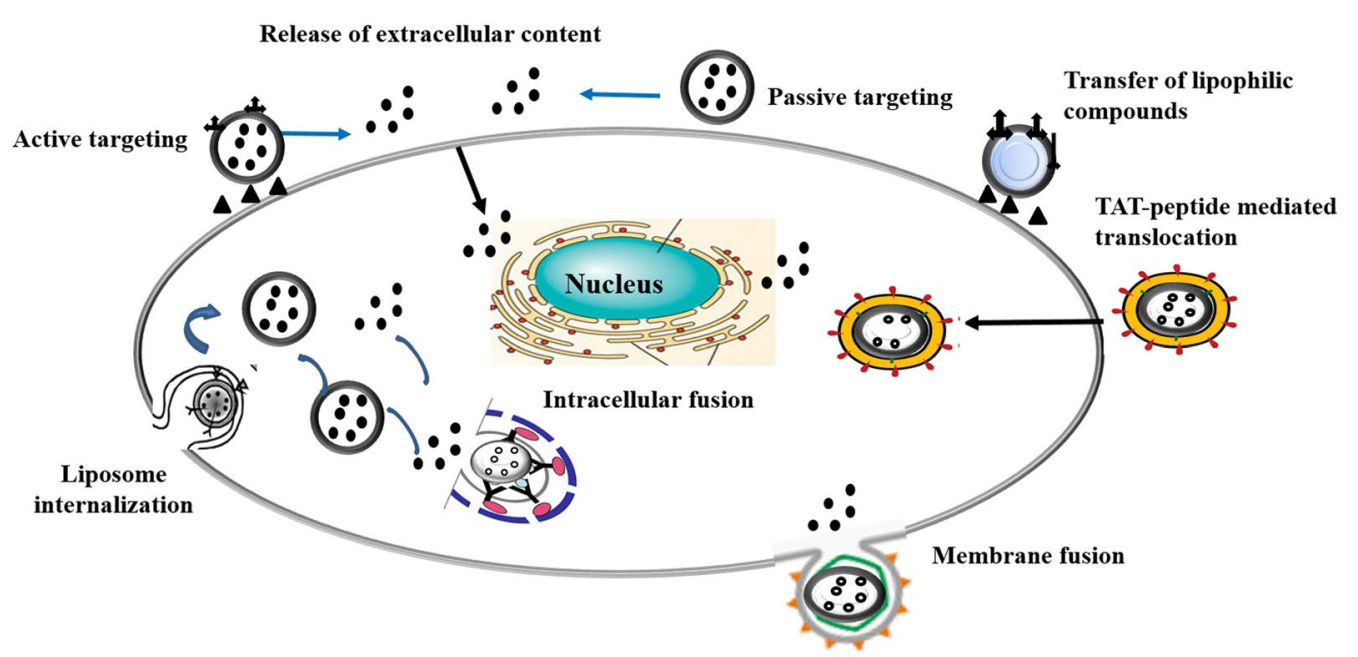

Fig. 5 Liposome as a drug delivery system (TAT_transactivator of transcription) (modified from Shaheen et al. 2006)

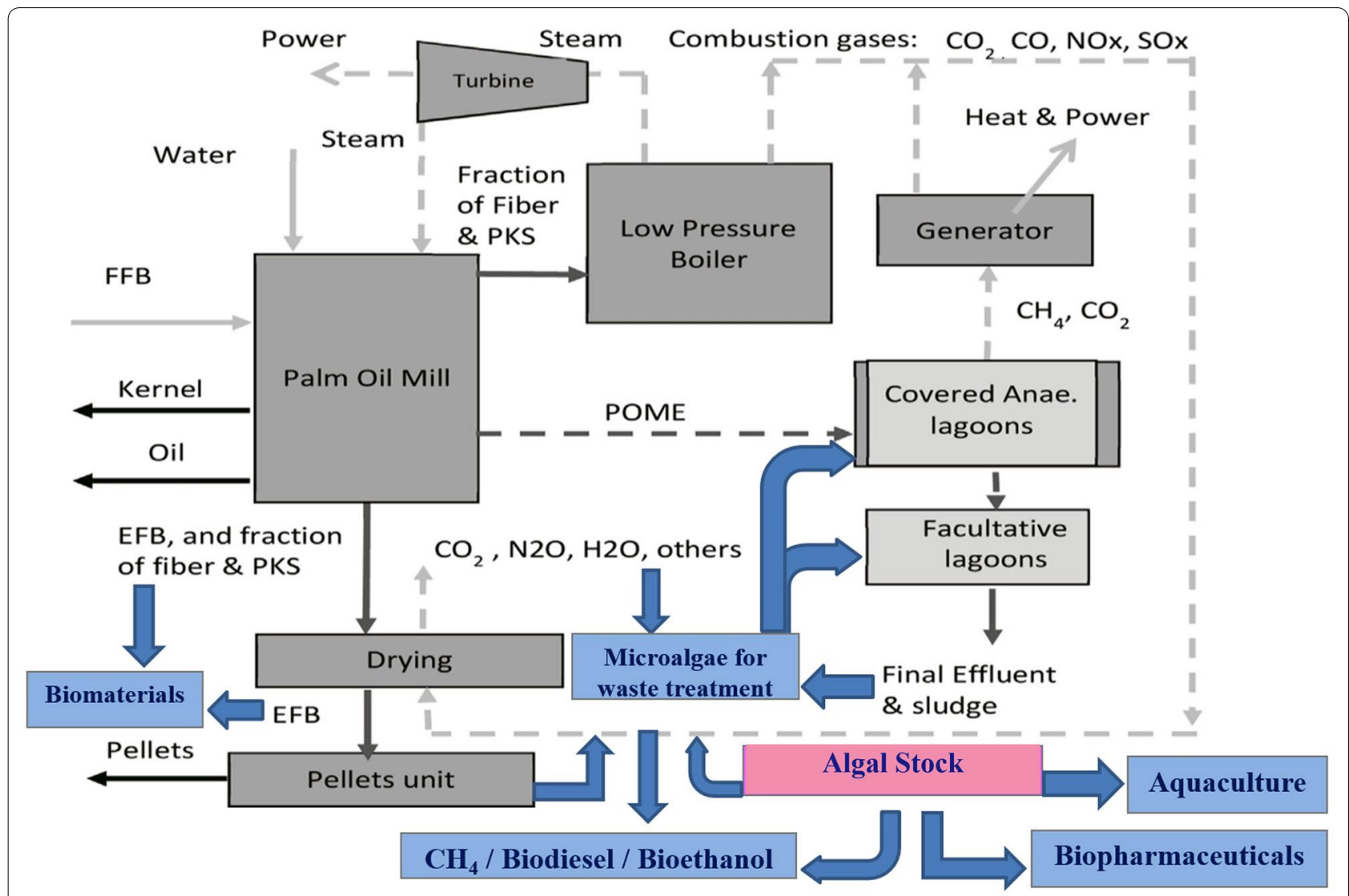

Fig. 6 The integrated algal and oil palm biorefinery (modified from Garcia-nunez et al. 2016; Abdullah and Hussein 2020)

the global perspective. A simple flowchart on biofuels production may exhibit the policy formulated, but for the policy to be an essential part of the LCA framework, system boundaries must be well-defined according to the scope and the goal set. For instance, if bioethanol production is analysed within the boundary of the well-to-tank 
(WtT) system, the engine's fuel combustion may have no direct impact in the LCA. However, the outcomes will be different, if the comparison of the bioethanol production is made with different fossil fuels or their mixture, within the same boundary system (Rathore et al. 2016). The economic and physical distribution based on energy and carbon content, mass (wet or dry), economic value, and system growth, are used to differentiate between the environmental load of production or process, and also to reflect the many functions within the same process (Rathore et al. 2016).

Palm oil accounts for one-third of the total vegetable oil production worldwide (Zahan and Kano 2018). The use of palm oil biodiesel is advantageous as its combustion does not add carbon dioxide, but just returning the carbon dioxide obtained earlier from photosynthesis, back into the atmosphere. The oil palm tree continues to absorb carbon dioxide throughout its 25-30 years of productive lifespan. The areas planted with oil palm in Malaysia also constitute only $2 \%$ of the land area globally dedicated to the oilseed crop planting (Basiron 2007). The economic viability of palm oil as a primary feedstock is attributed to the high oil content, low market price, abundant of resources and availability, and high productivity from lower farming areas as compared to the other oilseed crops (Zahan and Kano 2018). Based on the LCA, biodiesel from palm can decrease the GHG by $46-73 \%$ as compared to the diesel. The major environmental impacts are caused by the nitrogen-fertilizer production and its use in the oil palm plantation, and the emissions from the POME-treated ponds (Silalertruksa and Gheewala 2012a). The LCA carried out on the GHG emissions from the oil palm industry suggests the contributions from the Land-Use Change (LUC) for new areas of plantation, cultivation and harvesting, transportation, milling processes, conversion and processing into biodiesel and by-products, waste management and biodiesel usage (Silalertruksa and Gheewala 2012b). There are opportunities for more efficient utilization of fibres and shells, and biomethane from the wastewater treatment to improve the net energy ratio (NER) and net energy balance (NEB) (Pleanjai and Gheewala 2011). In the case of microalgal cultivation using raceway ponds and PBRs with only the production of biodiesel; and with both the production of $\omega-3$ fatty acids and biodiesel, the LCA suggests for the capital and operating cost reduction of at least $50 \%$ to make it profitable, even with higher revenue from $\omega-3$ fatty acid production (Sawaengsak et al. 2014).

The challenges to achieve commercial scale of microalgal biofuel are to identify high-lipid accumulating strain, to genetically engineer the strain with high tolerance to extreme environment, to achieve optimal engineering strategies for high productivity, efficient harvesting and product recovery, and support from the government (Rajesh Banu et al. 2020). The operation to enhance algal biomass productivity, and to achieve sustainable energy, water, nutrient/fertilizer, GHG emissions and land use across the entire value chain, must be systematically analysed based on techno-economic assesments and LCA (Laurens et al. 2017). There is a need to optimize the design for effective conversion into biodiesel with high productivity and high quality at minimal production cost and environmental impacts. A comprehensive strategy must be established to transport the wastes from the production sites and facilities; and to improve the reaction and conversion into biofuels, and the performance and effects on the engine. The improvements from LCA and sustainability studies should generate cheaper, environmentally friendly and high quality biofuels (Zahan and Kano 2018). Apart from the microalgae-oil palm biorefinery, the other routes may include the oil recovery, generation of biogas and sugar feedstocks and thermo-chemical processes (Shah and Abdullah 2017). The co-production of biofertilizers, biocomposites, commodity chemicals and aquaculture and animal feeds (Tran et al. 2017), biopharmaceuticals, EPA-rich oil and proteins (Chua and Schenk 2017; Shah and Abdullah 2017), are among the considerations to be made to further make the integrated algae-oil palm biorefinery, a more socially, environmentally and economically viable option. It is also high-time that the new concept, HEESBA (for Health consciousness; Environmental and safety awareness; Energy sufficiency; Social inclusiveness; Business acumen; Adaptability and agility), be embedded in the education curriculum, and practised in the government and private sector administration. "Hisbah", which in Arabic means "Accountability", should make Profit, Society and Wisdom as the key parameters in evaluating the Outcomes and Performances of any initiatives and endeavours. This is important to produce a new generation of politicians, policy makers, economists, business people, social scientists, engineers, industrialists, technocrats and the communities, that are more adaptable, and responsible, and with wisdom, could formulate the strategies and work out the solutions to the challenges confronting the society and the world, to meet the goals of economic and environmental sustainability, and social equitability.

\section{Conclusions}

Integrated algal and oil palm biorefinery can pave the way towards achieving the global sustainable development goals to address the issues and impacts of climate change and green-house gas emission. The provision of clean and affordable energy, and the promotion of decent work and economic growth through 
green industry, innovation, and infrastructure, could at the same time reduce inequality, create sustainable cities and communities, which practise responsible production and consumption. These can be accomplished by reutilizing the oil palm residues, bioenergy co-generation, and waste treatment, with microalgal co-cultivation and conversion into value-added products. The extraction of high-value biochemicals and the development of biomaterial-based products could further improve the economic aspects. The algal cultivation as an alternative molecular pharming system could facilitate in the drug development based on algal natural compounds, either directly as drugs or as key molecules for the synthesis of biochemical drugs. The algal bioactive compounds could add value and improve the economic competitiveness of a biorefinery for a wide range of application including food industries, novel enzyme and drug discovery, microbial and plant biotechnology, pharmacology, toxicology, and systems biology. The life-cycle analysis incorporating economic performance, environmental and social impact indicators provide optimal options for a more informed and knowledge-based decision-making process.

\section{Supplementary Information}

The online version contains supplementary material available at https://doi. org/10.1186/s40643-021-00396-0.

Additional file 1: Fig. S1. Applications of metabolomics (modified from Gomez-Casati et al. 2013, metabolomics in plants and humans: applications in the prevention and diagnosis of diseases. BioMed Research International, 1-11). Fig. S2. Flow diagram of the metabolomics studies (modified from Sas et al. 2015, Metabolomics and diabetes: Analytical and computational approaches. American Diabetes Association, 64:718-732).

\section{Acknowledgements}

The authors thank Universiti Malaysia Terengganu and University of Basrah for the support.

\section{Authors' contributions}

The authors have contributed equally to this work. Both the authors have read and approved the final manuscript.

\section{Funding}

Not applicable.

Availability of data and materials

The data and materials will be made available upon request.

\section{Declarations}

Ethical approval and consent to participate

Not applicable.

\section{Consent for publication}

All authors have consented to the publication of the manuscript.

\section{Competing interests}

There are no competing interests to declare.

\section{Author details}

${ }^{1}$ Institute of Marine Biotechnology, Universiti Malaysia Terengganu, 21030 Kuala Nerus, Terengganu, Malaysia. ${ }^{2}$ College of Dentistry, University of Basrah, Basrah, Iraq.

Received: 29 January 2021 Accepted: 11 May 2021

Published online: 20 May 2021

\section{References}

Abd El Baky HH, El Baz FK, El Baroty GS, Asker MMS, Ibrahim EA (2014) Phospholipids of some marine microalgae: identification, antivirus, anticancer and antimicrobial bioactivities. Der Pharma Chem 6:9-18

Abdel-Hady H, El-sayed MM, Abdel-gawad MM, El-wakil EA, Abdel-Hameed ES, Abdel-Lateef EE (2018) LC-ESI-MS analysis, antitumor and antioxidant activities of methanolic extract of Egyptian Allium kurrat. J Appl Pharm Sci 8:085-092

Abdullah MA, Ahmad A (2016) Integrated Algal Industrial Waste Treatment and Bioenergy Co- Generation. In: Sangeetha J, Thangadurai D, David M, Abdullah MA (Ed) Environ Biotechnol Biodegrad Bioremediation, Bioconversion Xenobiotics Sustain Dev CRC Press, Boco Raton: Florida. pp. 153-223.

Abdullah MA, Hussein HA (2020) Integrated algal biorefinery and palm oil milling for bioenergy, biomaterials and biopharmaceuticals. IOP Conf Ser Earth Environ Sci 463:012084. https://doi.org/10.1088/1755-1315/ 463/1/012084

Abdullah N, Sulaiman F, Gerhauser H (2011) Characterisation of oil palm empty fruit bunches for fuel application. J Phys Sci 22:1-24

Abdullah MA, Gul-e-Saba AA, Abdah A (2014) Cytotoxic effects of drug-loaded hyaluronan-glutaraldehyde cross-linked nanoparticles and the release kinetics modeling. J Adv Chem Eng 1:1000104

Abdullah MA, Shah S, Ahmad A, El-Sayed H (2015) Algal biotechnology for bioenergy, environmental remediation and high-value biochemicals. In: Thangadurai D, Sangeetha J (eds) Biotechnology and bioinformatics. Advances and applications for bioenergy, bioremediation and biopharmaceutical research. CRC Press, Apple Academic Press, New Jersey, pp 301-344

Abdullah MA, Ahmad A, Shah SMU, Shanab SMM, Ali HEA, Abo-State MAM, Othman MF (2016a) Integrated algal engineering for bioenergy generation, effluent remediation, and production of high-value bioactive compounds. Biotechnol Bioprocess Eng 21:236-249

Abdullah MA, Nazir MS, Raza MR, Wahjoedi BA, Yussof AW (2016b) Autoclave and ultra-sonication treatments of oil palm empty fruit bunch fibers for cellulose extraction and its polypropylene composite properties. J Clean Prod 126:686-697

Abdullah MA, Shah SMU, Shanab SMM, Ali HEA (2017a) Integrated algal bioprocess engineering for enhanced productivity of lipid, carbohydrate and high-value bioactive compounds. Res Rev J Microbiol Biotechnol. 6:61-92

Abdullah MA, Nazir MS, Ajab H, Daneshfozoun S, Almustapha S (2017b) Advances in eco-friendly pre- treatment methods and utilization of agro-based lignocelluloses. In: Thangadurai D, Sangeetha J (eds) Industrial biotechnology. Sustainable production and bioresource utilization. CRC Press, Apple Academic Press, New Jersey, pp 371-420

About the sustainable development goals (2019) About the Sustainable Development Goals-United Nations. https://www.un.org/sustainabl edevelopment/sustainable-development-goals/. Accessed on $29 \mathrm{Oct}$ 2019.

Adarme-Vega T, Thomas-Hall S, Lim D, Schenk P (2014) Effects of long chain fatty acid synthesis and associated gene expression in microalga Tetraselmis sp. Mar Drugs 12:3381-3398

Adhoni SA, Thimmappa SC, Kaliwal BB (2016) Phytochemical analysis and antimicrobial activity of Chlorella vulgaris isolated from Unkal Lake. J Coast Life Med 4:368-373

Ahmad A, Shah SMU, Othman MF, Abdullah MA (2014) Enhanced palm oil mill effluent treatment and biomethane production by co-digestion 
of oil palm empty fruit bunches with Chlorella sp. Can J Chem Eng 92:1636-1642

Ahmad A, Shah SMU, Othman MF, Abdullah MA (2015) Aerobic and anaerobic co-cultivation of Nannochloropsis oculata with oil palm empty fruit bunch for enhanced biomethane production and palm oil mill effluent treatment. Desalin Water Treat 56:2055-2065

Ahmad A, Shah SMU, Buang A, Abdullah MA (2016) Anaerobic co-cultivation of multi-algal species with oil palm empty fruit bunches for mill effluent treatment and biomethane production. J Teknol 78:5-6

Aiyegoro OA, Okoh Al (2010) Preliminary phytochemical screening and in vitro antioxidant activities of the aqueous extract of Helichrysum longifolium DC. BMC Complement Altern Med 10:21

Ajab H, Dennis JO, Abdullah MA (2018) Synthesis and characterization of cellulose and hydroxyapatite-carbon electrode composite for trace plumbum ions detection and its validation in blood serum. Int J Biol Macromol 113:376-385

Ajab H, Khan AAA, Nazir MS, Yaqub A, Abdullah MA (2019) Cellulosehydroxyapatite carbon electrode composite for trace plumbum ions detection in aqueous and palm oil mill effluent: interference, optimization and validation studies. Environ Res 176:108563

Ajab H, Khan AAA, Nazir MS, Yaqub A, Rozaini MZH, Abdullah MA (2020) Optimization of oil-palm based cellulose-hydroxyapatite carbon composite electrode for trace $\mathrm{Pb}$ (II) ions detection in aqueous system. Bioresour 15:6273-6281

Akhabue CE, Ogogo JA (2018) Modelling and optimization of transesterification of palm kernel oil catalysed by calcium oxide derived from hen eggshell wastes. IFE J Sci 20:127-138

Ali HEA, Shanab SMM, Abo-State MAM, Shalaby EAA, Demerdash UMN, Abdullah MA (2014a) Determination of antioxidant activities and total phenolic contents of three cyanobacterial species. Appl Mech Mater 625:826-829

Ali HEA, Shanab SMM, Abo-State MAM, Shalaby EAA, Demerdash UMN, Abdullah MA (2014a) Determination of antioxidant activities and total phenolic contents of three cyanobacterial species. Appl Mech Mater 625:826-829

Amaro HM, Guedes AC, Malcata FX (2011) Antimicrobial activities of microalgae: An invited review. In: Méndez-Vilas A, ed. Sci against Microb Pathog Commun Curr Res Technol Adv. pp. 1272-1284.

Amaro HM, Barros R, Guedes AC, Sousa-Pinto I, Malcata FX (2013) Microalgal compounds modulate carcinogenesis in the gastrointestinal tract. Trends Biotechnol 31:92-98

Amri RY, Saba AK, Asfarina A, Putra RS (2019) Production of hydrogen gas from biomass oil palm empty fruit bunch using electrolysis method. MATEC Web Conferences 268:06017

Appelt HR, Oliveira JS, Santos RCV, Rodrigues OED, Santos MZ, Heck EF, Rosa LC (2013) Synthesis and antimicrobial activity of carbohydrate based schiff bases: importance of sugar moiety. Int J Carbohydr Chem 2013:5

Arad SM, Levy-ontman O (2010) Red microalgal cell-wall polysaccharides: biotechnological aspects. Curr Opin Biotechnol 21:358-364

Arora S, Kumar G (2017) Gas Chromatography-Mass Spectrometry (GC-MS) determination of bioactive constituents from the methanolic and ethyl acetate extract of Cenchrus setigerus Vahl (Poaceae). Pharma Innov J 6:635-640

Azim NH, Subki A, Yusof ZNB (2018) Abiotic stresses induce total phenolic, total flavonoid and antioxidant properties in Malaysian indigenous microalgae and cyanobacterium. Malays J Microbiol 14:25-33

Azizan A, Bustamam MSA, Maulidiani M, Shaari K, Ismail IS, Nagao N, Abas F (2018) Metabolite profiling of the microalgal diatom Chaetoceros calcitrans and correlation with antioxidant and nitric oxide inhibitory activities via 1H NMR-based metabolomics. Mar Drugs 16:154

Banu RJ, Preethi KS, Gunasekaran M, Kumar G (2020) Microalgae based biorefinery promoting circular bioeconomy-techno economic and life-cycle analysis. Bioresour Technol 302:122822

Barredo JL (2012) Microbial carotenoids from bacteria and microalgae: methods and protocols. Human Press, pp 1-355.

Bartels JR, Pate MB, Olson NK (2010) An economic survey of hydrogen production from conventional and alternative energy sources. Internat J Hydr Energ 35:8371-8384

Basiron Y (2007) The palm oil advantage in biofuel. http://mpoc.org.my/thepalm-oil-advantage-in-biofuel/. Accessed 11 Aug 2020.
Begum S, Saad MFM (2013) echno-economic analysis of electricity generation from biogas using palm oil waste. Asian J Sci Res 6:290-298

Behrens PW, Kyle DJ (1996) Microalgae as a source of fatty acids. J Food Lipids 3:259-272

Bhagavathy S, Sumathi P, Bell IJS (2011) Green algae Chlorococcum humicolaa new source of bioactive compounds with antimicrobial activity. Asian Pac J Trop Biomed 1:S1-S7

Bhattacharjee M (2016) Pharmaceutically valuable bioactive compounds of algae. Asian J Pharm Clin Res 9:43

Bleakley S, Hayes M (2017) Algal proteins: extraction, application, and challenges concerning production. Foods 6(5):33

Boden TA, Marland G, Andres RJ (2010) Global, regional, and national fossil-fuel $\mathrm{CO} 2$ emissions.

Bouatra S, Aziat F, Mandal R, Guo AC, Wilson MR, Knox C et al (2013) The human urine metabolome. PLOS ONE 8:e73076

Braga LB, Silveira JL, Da Silva ME, Tuna CE, Machin EB, Pedroso DT (2013) Hydrogen production by biogas steam reforming: a technical, economic and ecological analysis. Renew Sustain Energ Rev 28:166-173

Brennan L, Owende P (2010) Biofuels from microalgae-a review of technologies for production, processing, and extractions of biofuels and co-products. Renew Sustain Energy Rev 14:557-577

Bruno A, Rossi C, Marcolongo G, Di Lena A, Venzo A, Berrie CP, Corda D (2005) Selective in vivo anti-inflammatory action of the galactolipid monogalactosyldiacylglycerol. Eur J Pharmacol 524:159-168

Budzianowski WM (2017) High-value low-volume bioproducts coupled to bioenergies with potential to enhance business development of sustainable biorefineries. Renew Sustain Energy Rev 70:793-804

Bule MH, Ahmed I, Maqbool F, Bilal M, Iqbal HMN (2018) Microalgae as a source of high-value bioactive compounds. Front Biosci Sch 10:197-216

Cabrita MT, Vale C, Rauter AP (2010) Halogenated compounds from marine algae. Mar Drug 8:2301-2317

Cardozo KHM, Guaratini T, Barros MP, Falcão VR, Tonon AP, Lopes NP et al (2007) Metabolites from algae with economical impact. Comp Biochem Physiol Part C 146:60-78

Cha KH, Koo SY, Lee DU (2008) Antiproliferative effects of carotenoids extracted from Chlorella ellipsoidea and Chlorella vulgaris on human colon cancer cells. J Agric Food Chem 56:10521-10526

Chang SH (2014) An overview of empty fruit bunch from oil palm as feedstock for bio-oil production. Biomass Bioenerg 62:174-181

Charmondusit K, Gheewala SH, Mungcharoen T (2016) Green and sustainable innovation for cleaner production in the Asia-Pacific region. J Clean Prod 134:443-446

Chaval parit O, Rulkens WH, Mol APJ, Khaodhair S (2006) Options for environmental sustainability of the crude palm oil industry in Thailand through enhancement of industrial ecosystems. Environ Dev Sustain 8:271-272

Chemmangattuvalappil NG, Ng DKS (2013) A systematic methodology for optimal product design in an integrated biorefinery. Comput Aided Chem Eng, vol. 32. Elsevier B.V.

Chiew YL, Shimada S (2013) Current state and environmental impact assessment for utilizing oil palm empty fruit bunches for fuel, fiber and fertilizer-a case study of Malaysia. Biomass Bioenerg 51:109-124

Chisti Y (2007) Biodiesel from microalgae. Biotechnol Adv 25:294-306

Christaki E, Florou-Paneri P, Bonos E (2011) Microalgae: a novel ingredient in nutrition. Int J Food Sci Nutr 62:794-799

Christenson L, Sims R (2011) Production and harvesting of microalgae for wastewater treatment, biofuels, and bioproducts. Biotechnol Adv 29:686-702

Chua ET, Schenk PM (2017) A biorefinery for Nannochloropsis: induction, harvesting, and extraction of EPA-rich oil and high-value protein. Bioresour Technol 244:1416-1424

Clarens AF, Resurreccion EP, White MA, Colosi LM (2010) Environmental life cycle comparison of algae to other bioenergy feedstocks. Environ Sci Technol 44:1813-1819

Cordero BF, Obraztsova I, Couso I, Leon R, Vargas MA, Rodriguez H (2011) Enhancement of lutein production in Chlorella sorokiniana (chorophyta) by improvement of culture conditions and random mutagenesis. Mar Drugs 9:1607-1624

Crupi P, Toci AT, Mangini S, Wrubl F, Rodolfi L, Tredici MR et al (2013) Determination of fucoxanthin isomers in microalgae (Isochrysis sp.) by high-performance liquid chromatography coupled with diode-array detector 
multistage mass spectrometry coupled with positive electrospray ionization. Rapid Commun Mass Spectrom 27:1027-1035

Custódio L, Soares F, Pereira H, Rodrigues MJ, Barreira L, Rauter AP et al (2015) Botryococcus braunii and Nannochloropsis oculata extracts inhibit cholinesterases and protect human dopaminergic SH-SY5Y cells from H2O2-induced cytotoxicity. J Appl Phycol 27:839-848

Daneshfozoun S, Abdullah MA, Abdullah B (2017) Preparation and characterization of magnetic biosorbent based on oil palm empty fruit bunch fibers, cellulose and Ceiba pentandra for heavy metal ions removal. Ind Crops Prod 105:93-103

Danielewicz MA, Anderson LA, Franz AK (2011) Triacylglycerol profiling of marine microalgae by mass spectrometry. J Lipid Res 52:2101-2108

De La Mare JA, Lawson JC, Chiwakata MT, Beukes DR, Edkins AL, Blatch GL (2012) Quinones and halogenated monoterpenes of algal origin show anti-proliferative effects against breast cancer cells in vitro. Invest New Drugs 30:2187-2200

De Morais M, da Silva VB, De GrequeCosta EMVJA (2015) Biologically active metabolites synthesized by microalgae. Biomed Res Int 2015:1-15

Debowski M, Zielinski M, Kazimierowicz J, Kujawska N, Talbierz S (2020) Microalgae cultivation technologies as an opportunity for bioenergetic system development—advantages and limitations. Sustainability 12:9980

Deeming-Adams B, Adams W (2002) Antioxidants in phothosynthesis and human nutrition. Science 80(298):2149-2153

Devi JS, Bhimba BV (2012) Anticancer activity of silver nanoparticles synthesized by the seaweed Ulva lactuca in vitro. Sci Rep 1:242

Dicks AL (1996) Hydrogen generation from natural gas for the fuel cell systems of tomorrow. J Power Sourc 61:113

Di Giuliano A, Girr J, Massacesi R, Gallucci K, Courson C (2017) Sorption enhanced steam methane reforming by $\mathrm{Ni}-\mathrm{CaO}$ materials supported on mayenite. Internat J Hydr Energ 42:13661-13680

Diglio G, Hanak DP, Bareschino P, Mancusi E, Pepe F, Montagnaro F, Monovic V (2017) Techno-economic analysis of sorption-enhanced steam methane reforming in a fixed bed reactor network integrated with fuel cell. J Power Sourc 364:41-51

Dineshkumar R, Narendran R, Jayasingam P, Sampathkumar P (2017) Cultivation and chemical composition of microalgae Chlorella vulgaris and its antibacterial activity against human pathogens. J Aquacult Mar Biol 5:00119

Ebrahimzadeh MA, Khalili M, Dehpour AA (2018) Antioxidant activity of ethyl acetate and methanolic extracts of two marine algae, Nannochloropsis oculata and Gracilaria gracilis —an in vitro assay. Brazilian J Pharm Sci 54:17280

El-Baky HHA, El Baz FK, El-Baroty GS (2009) Production of phenolic compounds from Spirulina maxima microalgae and its protective effects. African J Biotechnol 8:7059-7067

El-hack MEA, Abdelnour S, Alagawany M, Abdo M, Sakr MA, Khafaga AF et al (2019) Microalgae in modern cancer therapy: current knowledge. Biomed Pharmacother 111:42-50

El Gamal AA (2010) Biological importance of marine algae. Saudi Pharm J 18:1-25

Fabregas J, Herrero C (1990) Vitamin content of four marine microalgae. Potential use as source of vitamins in nutrition. J Ind Microbiol 5:259-260

Faroogi AA, Butt G, Razzaq Z (2012) Algae extracts and methyl jasmonate anti-cancer activities in prostate cancer: choreographers of 'the dance macabre.' Cancer Cell Int 12:50

Farshchi Tabrizi F, Seyed Mousavi SAH, Atashi H (2015) Thermodynamic analysis of steam reforming of methane with statistical approaches. Energ Conservat Manag 103:1065-1077

Fiehn O (2002) Metabolomics-the link between genotypes and phenotypes. Plant Mol Biol 48:155-171

Food and Agriculture Organization (2020). The State of World Fisheries and Aquaculture 2020-sustainability in action, Rome.https://doi.org/10 4060/ca9229en Accessed 30 Apr 2021

Francavilla M, Colaianna M, Zotti M, Morgese MG, Trotta P, Tucci P et al (2012) Extraction, characterization and in vivo neuromodulatory activity of phytosterols from microalga Dunaliella tertiolecta. Curr Med Chem 19:3058-3067

Gajaria TK, Suthar P, Baghel RS, Balar NB, Sharnagat P, Mantri VA, Reddy CRK (2017) Integration of protein extraction with a stream of byproducts from marine macroalgae: a model forms the basis for marine bioeconomy. Bioresour Technol 243:867-873
Gangadharan P, Kanchi KC, Lou HH (2012) Evaluation of the economic and environmental impact of combining dry reforming with steam reforming of methane. Chem Eng Res Des 90:1956-1968

Garcia-nunez JA, Ramirez-contreras NE, Rodrigueza DT, Silva-Lorab E, Frearc CS, Stocklec C, Garcia-Perez M (2016) Evolution of palm oil mills into bio-refineries: literature review on current and potential uses of residual biomass and effluent. Resour Conserv Recycl 110:99-114

Gheewala SH, Damen B, Shi X (2013) Biofuels: economic, environmental and social benefits and costs for developing countries in Asia. Wiley Interdiscip Rev Clim Chang 4:497-511

Giraldo JAP, Ortiz Sanchez M, Solarte-Toro JC, Cardona Alzate CA (2020). Economic and social aspects of biorefineries. Recent advances in bioconversion of lignocellulose to biofuels and value-added chemicals within the biorefinery concept, pp. 199-231. INC.

Goiris K, De Vreese P, De Cooman L, Muylaert K (2012) Rapid screening and guided extraction of antioxidants from microalgae using voltammetric methods. J Agric Food Chem 60:7359-7366

Goiris K, Muylaert K, Fraeye I, Brabanter J De (2012b) Antioxidant potential of microalgae in relation to their phenolic and carotenoid content

Gomez-casati DF, Zanor MI, Busi MV (2013) Metabolomics in plants and humans: applications in the prevention and diagnosis of diseases. Biomed Res Int 2013:1-11

Gouvea DR, Gobbo-Neto L, Sakamoto HT, Lopes NPLJLC, Meloni F, Amaral JG (2012) Seasonal variation of the major secondary metabolites present in the extract of Eremanthus mattogrossensis Less (Asteraceae: Vernonieae) leaves. Quim Nova 35:2139-2145

Guedes AC, Amaro HM, Malcata FX (2011) Microalgae as sources of carotenoids. Mar Drugs 9:625-644

Gul-e-Saba, Abdullah MA (2015) Polymeric nanoparticle mediated targeted drug delivery to cancer cells. In: Thangadurai D, Sangeetha J. Biotechnol Bioinforma Adv Appl Bioenergy Bioremediation Biopharm. Res. CRC Press/Apple Academic Press, New Jersey. pp. 1-34.

Hafsa MBEN, Ismail MBEN, Garrab M, Aly R, Gagnon J, Naghmouchi K (2017) Antimicrobial, antioxidant, cytotoxic and anticholinesterase activities of water-soluble polysaccharides extracted from microalgae Isochrysis galbana and Nannochloropsis oculata. J Serb Chem Soc 82:509-522

Hall R, Beale M, Fiehn O, Hardy N, Sumner L, Bino R (2002) Plant metabolomics: the missing link in functional genomics strategies. Plant Cell 14:1437-1441

Hanssen KØ (2014) Isolation and characterisation of bioactive secondary metabolites from arctic, marine organisms. PhD thesis, Centre for Research-based Innovation on Marine Bioactives and Drug Discovery (MabCent), Norwegian College of Fishery Science, Faculty of Biosciences, Fisheries and Economics, pp. 63

Hariram V, Prakash R, Seralathan S, Micha Premkumar T (2018) Data set on optimized biodiesel production and formulation of emulsified Eucalyptus teriticornisis biodiesel for usage in compression ignition engine. Data Brief 20:6-13

Harun R, Singh M, Forde GM, Danquah MK (2010) Bioprocess engineering of microalgae to produce a variety of consumer products. Renew Sustain Energy Rev 14:1037-1047

Hernandez B, Martin M (2016) Optimal process operation for biogas reforming to methanol: effects of dry reforming and bio-gas composition. Ind Eng Chem Res 55:6677-6685

Hernandez FYF, Khandual S, López IGR (2017) Cytotoxic effect of Spirulina platensis extracts on human acute leukemia Kasumi-1 and chronic myelogenous leukemia K-562 cell lines. Asian Pac J Trop Biomed 7:14-19

Herrero M, Mendiola JA, Cifuentes A, Tecnalia N (2013) Extraction of new bioactives from neochloris oleoabundans using pressurized technologies and food grade solvents. In III Iberoam Conf Supercrit Fluids. pp. 1-7

Hussein HA, Mohamad H, Ghazaly MM, Laith AA, Abdullah MA (2020a) Cytotoxic effects of Tetraselmis suecica chloroform extracts with silver nanoparticle co-application on MCF-7, 4T1, and Vero cell lines. J Appl Phycol 32:127-143

Hussein HA, Syamsumir DF, Mohd Radzi SA, Siong JYF, Mohamed Zin NA, Abdullah MA (2020b) Phytochemical screening, metabolite profiling and enhanced anti-microbial activities of microalgal crude extracts in co-application with silver nanoparticle. Bioresour Bioproc 7:39

Hussein HA, Mohamad H, Ghazaly MM, Laith AA, Abdullah MA (2020c) Anticancer and antioxidant activities of Nannochloropsis oculata and 
Chlorella sp. extracts in co-application with silver nanoparticle. J King Saud Uni Sci 32:3486-3494

Hussein HA, Maulidiani M, Abdullah MA (2020d) Microalgal metabolites as anti-cancer/anti-oxidant agents reduce cytotoxicity of elevated silver nanoparticle levels against non-cancerous Vero cells. Heliyon 6:e05263

lanora A, Boersma M, Casotti R, Fontana A, Harder J, Hoffmann F et al (2006) New trends in marine chemical ecology. Estuaries Coasts 29:531-551

IEA (2014) IEA (International Energy Agency). Bio-based chemicals. Value added products from biorefineries. IEA Bioenergy Task 42 Biorefining. Paris: IEA, 2014.

IEA Bioenergy (2012) https://www.ieabioenergy.com/blog/publications/biobased-chemicals-value-added-products-from-biorefineries. Accessed 30th Apr 2021

Imran Amran U, Ahmad A, Othman MR (2017) Kinetic based simulation of methane steam reforming and water gas shift for hydrogen production using Aspen Plus. Chem Eng Trans 56:1681-1686

Index Mundi (2019) Palm oil production by country in 1000 MT https://www. indexmundi.com/agriculture/?commodity=palm-oil. Accessed 19 Oct 2019

Ishola MM, Isroi TMJ (2014) Effect of fungal and phosphoric acid pretreatment on ethanol production from oil palm empty fruit bunches (OPEFB). Bioresour Technol 165:9-12

Ishola F, Adelekan D, Mamudu A, Abodunrin T, Aworinde A, Olatunji O, Akinlabi S (2020) Biodiesel production from palm olein: a sustainable bioresource for Nigeria. Heliyon. 6:03725

Jahnke LS (1999) Massive carotenoid accumulation in Dunaliella bardawil induced by ultraviolet-A radiation. J Photochem Photobiol B Biol 48:68-74

Jayappriyan KR, Rajkumar R, Venkatakrishnan V, Nagaraj S, Rengasamy R (2013) In vitro anticancer activity of natural $\beta$-carotene from Dunaliella salina EU5891199 in PC-3 cells. Biomed Prev Nutr 3:99-105

Jayshree A, Jayashree S, Thangaraju N (2016) Chlorella vulgaris and Chlamydomonas reinhardtii: Effective antioxidant, antibacterial and anticancer mediators. Indian J Pharm Sci 78:575-581

Kagana ML, Matulka RA (2015) Safety assessment of the microalgae Nannochloropsis oculata. Toxicol Rep 2:617-623

Kaiwen L, Bin Y, Tao Z (2018) Economic analysis of hydrogen production from steam reforming process: a literature review. Energ Sourc Part B: Econ Plan Polic 13:109-115

Kanchanasuta S, Sillaparassamee O (2017) Enhancement of hydrogen and methane production from co-digestion of palm oil decanter cake and crude glycerol using two stage thermophilic and mesophilic fermentation. Internat J Hydr Energ 42:3440-3446

Kannan RRR, Arumugam R, Anantharaman P (2010) Antibacterial potential of three seagrasses against human pathogens. As Pac J Trop Med 3:890-893

Kareem SO (2017) Enzymatic biodiesel production from palm oil and palm kernel oil using free lipase. Egypt J Pet 26:635-642

Kårlund A, Hanhineva K, Lehtonen M, Karjalainen RO, Sandell M (2015) Nontargeted metabolite profiles and sensory properties of strawberry cultivars grown both organically and conventionally. J Agric Food Chem 63:1010-1019

Kelly PN, Strasser A (2011) The role of BCl-2 and its pro-survival relatives in tumourigenesis and cancer therapy. Cell Death Differ 18:1414-1424. https://doi.org/10.1038/cdd.2011.17

Kermanshahi-pour A, Sommer TJ, Anastas PT, Zimmerman JB (2014) Enzymatic and acid hydrolysis of Tetraselmis suecica for polysaccharide characterization. Bioresour Technol 173:415-421

Khongkliang P, Jehlee A, Kongjan P, Reungsang A, O-Thong S, (2019) High efficient biohydrogen production from palm oil mill effluent by twostage dark fermentation and microbial electrolysis under thermophilic condition. Internat J Hydr Energ 44:31841-31852

Kim M, Han J, Kim S, Soo H, Ghil W, Jin S et al (2012) In vitro inhibition of influenza A virus infection by marine microalga-derived sulfated polysaccharide $\mathrm{p}-\mathrm{KGO3}$. Antiviral Res 93:253-259

Kim YS, Li XF, Kang KH, Ryu B, Kim SK (2014) Stigmasterol isolated from marine microalgae Navicula incerta induces apoptosis in human hepatoma HepG2 cells. BMB Rep 47:433-438

Kumneadklang S, Larpkiattaworn S, Niyasom C, O-Thong S, (2015) Bioethanol production from oil palm frond by simultaneous saccharification and fermentation. Energ Proc 79:784-790
Kurnia JC, Jangam SV, Akhtar S, Sasmito AP, Mujumdar AS (2016) Advances in biofuel production from oil palm and palm oil processing wastes: a review. Biofuel Res J 3:332-346

Kwon MJ, Nam TJ (2007) A polysaccharide of the marine alga Capsosiphon fulvescens induces apoptosis in AGS gastric cancer cells via an IGF-IRmediated PI3K/Akt pathway. Cell Biol Int 31:768-775

Laosiripojana N, Champreda V, Laosiriponana W, Daorattanachai P (2018) Integrative biorefinery technologies for efficient converting of lignocellulosic biomasses to biofuels, valorized chemicals and materials. J Sustain Energy Environ 9:89-92

Laurens LM, Chen-Glasser M, McMillan JD (2017) A perspective on renewable bioenergy from photosynthetic algae as feedstock for biofuels and bioproducts. Algal Res 24:261-264

Lawlor K, Day J, Van Damme I, Stanley M (2017) Marine microalgae as sources of phospholipids and sterols for use as nutraceuticals and encapsulation systems. Phycologia 56:112

Li B, Gao MH, Zhang XC, Chu XM (2006) Molecular immune mechanism of C-phycocyanin from Spirulina platensis induces apoptosis in HeLa cells in vitro. Biotechnol Appl Biochem 43:155

Li J, Zhu D, Niu J, Shen S, Wang G (2011) An economic assessment of astaxanthin production by large scale cultivation of Haematococcus pluvialis. Biotechnol Adv 29:568-574

Lim S, Lee KT, Pinang P (2011) Parallel production of biodiesel and bioethanol in palm-oil-based biorefineries: life cycle assessment on the energy and greenhouse gases. Biofuels Bioprod Biorefining 5:132-150

Lin AB, McNeely SC, Beckmann RP (2017) Achieving precision death with cell-cycle inhibitors that target DNA replication and repair. Clin Cancer Res 23:3232-3240

Liu J, Sun Z, Gerken H, Liu Z, Jiang Y, Chen F (2014) Chlorella zofingiensis as an alternative microalgal producer of astaxanthin: biology and industrial potential. Mar Drugs 12:3487-3515

Loh SK (2016) The potential of the Malaysian oil palm biomass as a renewable energy source. Energy Convers Manag 141:285-298

Lunprom S, Phanduang O, Salakkam A, Liao Q, Imai T, Reungsang A (2019) Bio-hythane production from residual biomass of Chlorella sp. biomass through a two-stage anaerobic digestion. Internat J Hydr Energ 44:3339-3346

Maadane A, Merghoub N, Ainane T, El AH, Benhima R, Amzazi S et al (2015) Antioxidant activity of some Moroccan marine microalgae: Pufa profiles, carotenoids and phenolic content. J Biotechnol 215:13-19

Maadane A, Merghoub N, El Mernissi N, Ainane T, Amzazi S, Wahby I, Bakri $Y$ (2017) Antimicrobial activity of marine microalgae isolated from Moroccan coastlines. J Microbiol Biotechnol Food Sci 6:1257-1260

Maaroff RM, Md Jahim J, Azahar AM, Abdul PM, Masdar MS, Nordin D, Abd Nasir MA (2019) Biohydrogen production from palm oil mill effluent (POME) by two stage anaerobic sequencing batch reactor (ASBR) system for better utilization of carbon sources in POME. Internat Hydr Energ 44:3395-3406

Makridis P, Jon A, Skjermo J, Vadstein O (2000) Control of the bacterial flora of Brachionus plicatilis and Artemia franciscana by incubation in bacterial suspensions. Aquacult 185:207-218

Malaysian Palm Oil Council (2019) Malaysian Palm Oil Council. Palm oil industry - a learning experience, http://mpoc.org.my/palm-oil-indus try-a-learning-experience/. 2019. Accessed 14 Oct 2019

Mamimin C, Singkhala A, Kongjan P, Suraraksa B, Prasertsan P, Imai T, O-Thong S, (2015) Two-stage thermophilic fermentation and mesophilic methanogen process for biohythane production from palm oil mill effluent. Internat J Hydr Energ 40:6319-6328

Mamimin C, Kongjan P, Thong S, Prasertsan P (2019) Enhancement of biohythane production from solid waste by co-digestion with palm oil mill effluent in two-stage thermophilic fermentation. Internat J Hydr Energ 44:17224-17237

Masarin F, Cedeno FRP, Chavez EGS, De Oliveira LE, Gelli VC, Monti R (2016) Chemical analysis and biorefinery of red algae Kappaphycus alvarezii for efficient production of glucose from residue of carrageenan extraction process. Biotechnol Biofuels 9(1):122

Matharasi A, Kumar RD, Prabakaran G, Kumar PS (2018) Phytochemical screening and antimicrobial activity of marine microalgae Tetraselmis sp. Int J Pharm Biol Sci 8:85-90 
Matich E (2018) LC-MS-based metabolomics analysis to determine the effect that varying growth conditions have on microalgae. PhD thesis, State University of New York at Buffalo, pp 155

Matsumoto Y, Sahara H, Fujita T, Hanashima S, Yamazaki T, Takahashi S et al (2000) A novel immunosuppressive agent, SQDG, derived from sea urchin. Transplant Proc 32:2051-2053

Mayer AMS, Gustafson KR (2008) Marine pharmacology in 2005-2006: antitumour and cytotoxic compounds. Eur J Cancer 44:2357-2387

Mekhilef S, Saidur R, Safari A, Mustaffa WESB (2011) Biomass energy in Malaysia: current state and prospects. Renew Sustain Energy Rev 15:3360-3370

Metsämuuronen S, Sirén H (2019) Bioactive phenolic compounds, metabolism and properties: a review on valuable chemical compounds in Scots pine and Norway spruce. Phytochem Rev 18:623-664

Mhatre A, Gore S, Mhatre A, Trivedi N, Sharma M, Pandit R, Anil A, Lali A (2019) Effect of multiple product extractions on bio-methane potential of marine macrophytic green alga Ulva lactuca. Renewable Energ 132:742-751

Michalak I, Chojnacka K (2015) Algae as production systems of bioactive compounds. Eng Life Sci 15:160-176

Minhas AK, Hodgson P, Barrow CJ, Adholeya A (2016) A review on the assessment of stress conditions for simultaneous production of microalgal lipids and carotenoids. Front Microbiol 7:546

Miranda MS, Cintra RG, Barros SBM, Mancini-Filho J (1998) Antioxidant activity of the microalga Spirulina maxima. Brazilian J Med Biol Res 31:1075-1079

Mofijur M, Masjuki HH, Kalam MA, Atabani AE, Rizwanul Fattah IM, Mobarak HM (2014) Comparative evaluation of performance and emission characteristics of Moringa oleifera and Palm oil based biodiesel in a diesel engine. Ind Crop Prod 53:78-84

Moheimani NR, Borowitzka MA (2006) The long-term culture of the coccolithophore Pleurochrysis carterae (Haptophyta) in outdoor raceway ponds. J Appl Phycol 18:703-712

Mojaat M, Pruvost J, Foucault A, Legrand J (2008) Effect of organic carbon sources and Fe2+ions on growth and $\beta$-carotene accumulation by Dunaliella salina. Biochem Eng J 39:177-184

Molazadeh M, Ahmadzadeh H, Pourianfar HR, Lyon S, Rampelotto PH (2019) The use of microalgae for coupling wastewater treatment with $\mathrm{CO}_{2}$ biofixation. Front Bioeng Biotechnol 7:42

de Monteiro LS, Bastos KX, Barbosa-Filho JM, Athayde-Filho PF, de Diniz MFFM, Sobral MV (2014) Medicinal plants and other living organisms with antitumor potential against lung cancer. Evid Compl Alternat Med 2014:1-15

Moussavou G, Kwak DH, Obiang-Obonou BW, Maranguy CAO, Dinzouna-Boutamba SD, Lee DH et al (2014) Anticancer effects of different seaweeds on human colon and breast cancers. Mar Drugs 12:4898-4911

Murugesan S, Bhuvaneswari S (2016) HPTLC fingerprint profile of methanol extract of the marine red alga Portieria hornemannii (Lyngbye) (Silva). Int J Adv Pharm 5:10-14

Mussatto SI, Loosdrecht M (2016) Cellulose: a key polymer for a greener, healthier, and bio-based future. Biofuel Res J 3:482-482

Namiki M (1990) Antioxidants/antimutagens in food. Crit Rev Food Sci Nutr 29:273-300

Namvar F, Baharara J, Mahdi AA (2014) Antioxidant and anticancer activities of selected persian gulf algae. Indian J Clin Biochem 29:13-20

Namvar F, Mohamad R, Baharara J, Zafar-balanejad S, Fargahi F, Rahman HS (2013) Antioxidant, antiproliferative, and antiangiogenesis effects of polyphenol-rich seaweed (Sargassum muticum). Biomed Res Int 2013:9

Nasrin AB, Ma AN, Choo YM, Mohamad S, Rohaya MH, Azali A, Zainal Z (2008) Oil palm biomass as potential substitution raw materials for commercial biomass briquettes production. Am J Appl Sci 5:179-183

Natrah FMI, Yusoff FM, Shariff M, Abas F, Mariana NS (2007) Screening of Malaysian indigenous microalgae for antioxidant properties and nutritional value. J Appl Phycol 19:711-718

Nazir MS, Wahjoedi BA, Yussof AW, Abdullah MA (2013) Eco-friendly extraction and characterization of cellulose from oil palm empty fruit bunches. Bioresourc 8:2161-2172

Nazir MS, Abdullah MA, Raza MR (2018) Polypropylene composite with oil palm fibers: method development: properties and applications. In: Visakh PM, Matheus P (eds) Polypropylene-based Biocomposites and Bionanocomposites. Scrivener Publishing, USA, pp 287-314
Nazir MS, Ajab H, Raza MR, Abdullah MA (2018) Surface modification of cellulose fibers from oil palm empty fruit bunches for heavy metal ion sorption and diesel desulphurization. Desalin Water Treat 107:241-256

Newman DJ, Cragg GM (2012) Natural products as sources of new drugs over the 30 years. J Nat Prod 75:311-335

Ng RTL, Ng DKS (2013) Systematic approach for synthesis of integrated palm oil processing complex. Part 1: single owner. Ind Eng Chem Res 52:10206-10220

Ng RTL, Ng DKS, Tan RR (2013) Systematic approach for Synthesis of integrated palm oil processing complex. Part 2: multiple owners. Ind Eng Chem Res 52:10221-10235

Ng RTL, Ng DKS, Tan RR (2015) Optimal planning, design and synthesis of symbiotic bioenergy parks. J Clean Prod 87:291-302

Nigjeh SE, Yusoff F, Alitheen NBM, Rasoli M, Keong YS, Omar ARB (2013) Cytotoxic effect of ethanol extract of microalga, Chaetoceros calcitrans, and its mechanisms in inducing apoptosis in human breast cancer cell line. Biomed Res Int 2013:8

Nishioka M, Bradshaw JS, Lee ML, Tominaga Y, Tedjamulia M, Castle RN (1985) Capillary column gas chromatography of sulfur heterocycles in heavy oils and tars using a biphenylpolysiloxane stationary phase. Analyt Chem 57:309

NREL (2015) NREL (National Renewable Energy Laboratory). What is a biorefinery? (http:// www.nrel.gov/biomass/biorefinery.html). Accessed 17 Aug 2020

Nurul Adela B, Nasrin AB, Loh SK, Choo YM (2014) Bioethanol production by fermentation of oil palm empty fruit bunches pretreated with combined chemicals. J Appl Environ Biol Sci 4:234-242

Obata T, Schoenefeld S, Krahnert I, Bergmann S, Scheffel A, Fernie AR (2013) Gas-chromatography mass-spectrometry (GC-MS) based metabolite profiling reveals mannitol as a majorstorage carbohydrate in the coccolithophorid alga Emiliania huxleyi. Metabolites 3:168-184

Oh J, Yoon D, Han J, Choi H, Sung G (2018) 1H NMR based metabolite profiling for optimizing the ethanol extraction of Wolfiporia cocos. Saudi J Biol Sci 25:1128-1134

Ohimain El, Izah SC (2017) A review of biogas production from palm oil mill effluents using different configurations of bioreactors. Renew Sustain Energy Rev 70:242-253

Olusanya TOB, Ahmad RRH, Ibegbu DM, Smith JR, Elkordy AA (2018) Liposomal drug delivery systems and anticancer drugs. Molecules 23:907

Omenn GS, Goodman GE, Thornquist MD, Balmes J, Cullen MR, Glass A et al (1996) Effects of a combination of Beta Carotene and vitamin A on lung cancer and cardiovascular disease. N Engl J Med 334:1150-1155

Othman R, Noh N, Nurrulhidayah AF, Anis Hamizah H, Jamaludin MA (2017) Determination of natural carotenoid pigments from freshwater green algae as potential halal food colorants. Int Food Res J 24:468-471

Thong OS, Suksong W, Promnuan K, Thipmunee M, Mamimin C, Prasertsan P (2016) Two-stage thermophilic fermentation and mesophilic methanogenic process for biohythane production from palm oil mill effluent with methanogenic effluent recirculation for $\mathrm{pH}$ control. Internat J Hydr Energ 41:21702-21712

Pan Z, Raftery D (2007) Comparing and combining NMR spectroscopy and mass spectrometry in metabolomics. Anal Bioanal Chem 387:525-527

Pasquet V, Morisset P, Ihammouine S, Chepied A, Aumailley L, Berard JB, Serive B, Kaas R, Lanneluc I, Thiery V, Lafferriere M, Piot JM, Patrice T, Cadoret JP, Picot $L$ (2011) Antiproliferative activity of violaxanthin isolated from bioguided fractionation of Dunaliella tertiolecta extracts. Mar Drugs 9:819-831

Pauli GA (2010) The Blue Economy- 10 Years, 100 Innovations 100 Million Jobs. Paradigm publications.

Pérez ATE, Camargo M, César P, Rincón N (2017) Key challenges and requirements for sustainable and industrialized biorefinery supply chain design and management: a bibliographic analysis. Renew Sustain Energy Rev 69:350-359

Piasecka A, Nawrocka A, Wiacek D, Krzeminska J (2020) Agro-industrial byproduct in photoheterotrophic and mixotrophic culture of Tetradesmus obliquus: production of $\omega 3$ and $\omega 6$ essential fatty acids with biotechnological importance. Sci Rep 10:1-11

Plaza M, Santoyo S, Jaime L, Reina GGB, Herrero M, Señoráns FJ, Ibáñez E (2010) Screening for bioactive compounds from algae. J Pharm Biomed Anal $51: 450-455$

Pleanjai S, Gheewala SH (2011) Full chain energy analysis of biodiesel production from palm oil in Thailand. Appl Energy 86:S209-S214 
Pokorn J (1991) Natural antioxidants for food use. Trends Food Sci Technol 2:223-227

Priyadarshani I, Rath B (2012) Commercial and industrial applications of micro algae-a review. J Algal Biomass UtIn 3:89-100

Psychogios N, Hau DD, Peng J, Guo AC, Mandal R, Bouatra S et al (2011) The human serum metabolome. PLoS ONE 6:e16957

Pulz O, Gross W (2004) Valuable products from biotechnology of microalgae. Appl Microbiol Biotechnol 65:635-648

Rajendran N, Karpanai Selvan B, Sobana Piriya P, Logeswari V, Kathiresan E, Tamilselvi A, John Vennison S (2014) Phytochemicals, antimicrobial and antioxidant screening from five different marine microalgae. $J$ Chem Pharm Sci 7:78-85

Ramberg JE, Nelson ED, Sinnott RA (2010) Immunomodulatory dietary polysaccharides: a systematic review of the literature. Nutr I 9:54

Ramos AA, Polle J, Tran D, Cushman JC, Jin ES, Varela JC (2011) The unicellular green alga Dunaliella salina Teod. as a model for abiotic stress tolerance: genetic advances and future perspectives. Algae 26:3-20

Rasmussen RS, Morrissey MT (2007) Marine biotechnology for production of food ingredients. Adv Food Nutr Res 52:237-292

Rathore D, Nizami A, Singh A, Pant D (2016) Key issues in estimating energy and greenhouse gas savings of biofuels: challenges and perspectives. Biofuel Res J 10:380-393

Reyna-Martinez R, Gomez-Flores R, López-Chuken U, Quintanilla-Licea R, Hernandez DC, Rodríguez-Padilla C, Tamez-Guerra P (2018) Antitumor activity of Chlorella sorokiniana and Scenedesmus sp. microalgae native of Nuevo León State, México. Peer J 6:4358

Rojas CM, Senthil-kumar M, Tzin V, Mysore KS (2014) Regulation of primary plant metabolism during plant-pathogen interactions and its contribution to plant defense. Front Plant Sci 5:17

Sacristán-soriano O, Banaigs B, Becerro MA (2012) Temporal trends in the secondary metabolite production of the sponge Aplysina aerophoba. Mar Drugs 10:677-693

Saini MK, Sanyal SN, Vaiphei K (2012) Piroxicam and C-phycocyanin mediated apoptosis in 1,2-dimethylhydrazine dihydrochloride induced colon carcinogenesis: exploring the mitochondrial pathway. Nutr Cancer 64:409-418

Saleh AF, Kamarudin E, Yaacob AB, Yussof AW, Abdullah MA (2012) Optimization of biomethane production by anaerobic digestion of palm oil mill effluent using response surface methodology. Asia-Pac J Chem Eng 7:353-360

Sanmukh S, Bruno B, Ramakrishnan U, Khairnar K, Swaminathan S, Paunikar W (2014) Bioactive compounds derived from microalgae showing antimicrobial activities. J Aquac Res Dev 5:3-6

Santhosh S, Dhandapani R, Hemalatha N (2016) Bioactive compounds from Microalgae and its different applications-a review. Adv Appl Sci Res 7:153-158

Sas KM, Karnovsky A, Michailidis G, Pennathur S (2015) Metabolomics and diabetes: analytical and computational approaches. Diabetes 64:718-732

Sathasivam R, Radhakrishnan R, HashemAllah AAEF (2019) Microalgae metabolites: a rich source for food and medicine. Saudi J Biol Sci 26:709-722

Sawaengsak W, Silalertruksa T, Bangviwat A, Gheewala SH (2014) Life cycle cost of biodiesel production from microalgae in Thailand. Energy Sustain Dev 18:67-74

Seengenyoung J, Mamimin C, Prasertsan P, O-Thong S, (2019) Pilot-scale of biohythane production from palm oil mill effluent by two-stage thermophilic anaerobic fermentation. Internat J Hydr Energ 44:3347-3355

Shah SM, Abdullah MA (2017) Nannochloropsis oculata and integrated biorefinery based on palm oil milling. In Nannochloropsis Biol. Biotechnol. potential Challenges. Marcel Jan \& Przemek Kazik (Eds.), Nova Science Publisher, New York. pp. 135-180

Shah SMU, Abdullah MA (2018) Effects of macro/micronutrients on green and brown microalgal cell growth and fatty acids in photobioreactor and open-tank systems. Biocatal Agric Biotechnol 14:10-17

Shah SMU, Ahmad A, Othman MF, Abdullah MA (2014) Enhancement of lipid content in Isochrysis Galbana and pavlova lutheri using palm oil mill effluent as an alternative medium. Chem Eng Trans 37:733-738

Shah SMU, Ahmad A, Othman MF, Abdullah MA (2016) Effects of palm oil mill effluent media on cell growth and lipid content of Nannochloropsis oculata and Tetraselmis suecica. Int J Green Energy 13:200-207
Shah SMU, Radziah CC, Ibrahim S, Latiff F, Othman MF, Abdullah MA (2014) Effects of photoperiod, salinity and $\mathrm{pH}$ on cell growth and lipid content of Pavlova lutheri. Ann Microbiol 64:157-164

Shaheen SM, Shakil Ahmed FR, Hossen MN, Ahmed M, Amran MS, UI-Islam MA (2006) Liposome as a carrier for advanced drug delivery. Pak J Biol Sci 9:1181-1191

Sharif N, Munir N, Saleem F, Aslam F, Naz S (2014) Prolific anticancer bioactivity of algal extracts (Review). Am J Drug Deliv Therape 3:8

Sijtsma L, De Swaaf ME (2004) Biotechnological production and applications of the $\omega-3$ polyunsaturated fatty acid docosahexaenoic acid. Appl Microbiol Biotechnol 64:146-153

Silalertruksa T, Gheewala SH (2012) Environmental sustainability assessment of palm biodiesel production in Thailand Oil palm production. Energy 43:306-314

Silalertruksa T, Gheewala SH (2012) Food, fuel, and climate change is palm-based biodiesel a sustainable option for Thailand? I Ind Ecol 16:541-551

Singh D, Puri M, Wilkens S, Mathur AS, Tuli DK, Barrow CJ (2013) Characterization of a new zeaxanthin producing strain of Chlorella saccharophila isolated from New Zealand marine waters. Bioresour Technol 143:308-314

Singh NK, Dhar DW (2011) Microalgae as second generation biofuel. A review. Agron Sustain Dev 31:605-629

Singh RP, Ibrahim MH, Esa N, lliyana MS (2010) Composting of waste from palm oil mill: a sustainable waste management practice. Rev Env Sci Biotechnol 9:331-344

Skibsted LH (2012) Carotenoids in antioxidant networks. Colorants or radical scavengers. J Agric Food Chem. 60:2409-2417

Smelcerovic A, Knezevic-jugovic Z, Petronijevic Z (2008) Microbial polysaccharides and their derivatives as current and prospective pharmaceuticals. Curr Pharm Des 14:3168-3195

Song C (2010) Introduction to hydrogen and syngas production and purification technologies. In: Liu K, Song C, Subramani V (eds) Hydrogen and syngas production and purification technologies. Wiley, Hoboken, NJ, USA, pp 1-13

Song C, Ma X (2010) Desulfurization technologies. In: Liu K, Song C, Subramani $\checkmark$ (eds) Hydrogen and syngas production and purification technologies. Wiley, Hoboken, NJ, pp 219-310

Song H, Ozkan US (2010) Economic analysis of hydrogen production through a bioethanol steam reforming process: sensitivity analyses and cost estimations. Internat J Hydr Energ 35:127-134

Soontornchaiboon W, Joo SS, Kim SM (2012) Anti-inflammatory effects of violaxanthin isolated from microalga Chlorella ellipsoidea in RAW 264.7 macrophages. Biol Pharm Bull 35:1137-1144

Specht E, Miyake-stoner S, Mayfield S (2010) Micro-algae come of age as a platform for recombinant protein production. Biotechnol Lett 32:1373-1383

Spratlin JL, Serkova NJ, Eckhardt SG (2009) Clinical applications of metabolomics in oncology: a review. Clin Cancer Res 15:431-441

Stengel DB, Connan S, Popper ZA (2011) Algal chemodiversity and bioactivity: sources of natural variability and implications for commercial application. Biotechnol Adv 29:483-501

Stringer KA, Mckay RT, Karnovsky A, Quémerais B, Lacy P (2016) Metabolomics and its application to acute lung diseases. Front Immunol 7:44

Subramani V, Sharma P, Zhang L, Liu K (2010) Catalytic steam reforming technology for the production of hydrogen and syngas. In: Liu K, Song C, Subramani V (eds) Hydrogen and syngas production and purification technologies. Wiley, Hoboken, NJ, pp 14-126

Suganya T, Varman M, Masjuki HH, Renganathan S (2016) Macroalgae and microalgae as a potential source for commercial applications along with biofuels production: a biorefinery approach. Renew Sustain Energy Rev 55:909-941

Sukhang S, Choojit S, Reungpeerakul T, Sangwichien C (2020) Bioethanol production from oil palm empty fruit bunch with SSF and SHF processes using Kluyveromyces marxianus yeast. Cellulose 27:301-314

Sulaiman F, Abdullah N, Gerhauser H, Shariff A (2011) An outlook of Malaysian energy, oil palm industry and its utilization of wastes as useful resources. Biomass Bioenerg 35:3775-3786

Suriyakala PC, Satheesh Babu N, Senthil Rajan D, Prabakaran L (2014) Phospholipids as versatile polymer in drug delivery systems. Int J Pharm Pharm Sci 6:8-11 
Syahril MZM, Roshani O, Hasyimah RN, Hafiz MSM, Sharida MD, Ahmed HY (2011) Screening of anticancer activities of crude extracts of unicellular green algae (Chlorella vulgaris) and filamentous blue green algae (Spirulina platensis) on selected cancer cell lines. Int Conf Appl Sci Math Humanit. pp. 82-87

Takaichi S (2011) Carotenoids in algae: distributions, biosyntheses and functions. Mar Drugs 9:1101-1118

Talero E, García-Mauriño S, Ávila-Román J, Rodríguez-Luna A, Alcaide A, Motilva V (2015) Bioactive compounds isolated from microalgae in chronic inflammation and cancer. Mar Drugs 13:6152-6209

Tallima H, El Ridi R (2018) Arachidonic acid: physiological roles and potential health benefits-a review. J Adv Res 11:33-41

Theo WL, Lim JS, Ho WS, Hashim H, Lee CT, Muis A (2017) Optimisation of oil palm biomass and palm oil mill effluent (POME) utilisation pathway for palm oil mill cluster with consideration of BioCNG distribution network. Energy 121:865-883

Tiwari G (2013) Preparation and characterization of ketoconazole encapsulated liposome and ethosome: a comparative study. MSc. National institute of Biotechnology

Tran DT, Do TCV, Nguyen QT, Le TG, Nguyen QT, Nguyen VT (2017) Recent advances in the utilization of Nannochloropsis biomass for commodity chemicals, feeds, high-value products, biofuels, cosmetics, fertilizers and materials production. In: Jan P, Kazik M, eds. Nannochloropsis Biol Biotechnol potential Challenges. Nova Science Publisher, New York. pp. 75-133

Tuan HP, Janssen HG, Cramers CA, Smit ALC, Loo EM (1994) Determination of sulfur components in natural gas: a review. J High Resolut Chromatogr 17:373-389

Ubando AT, Felix CB, Chen WH (2020) Biorefineries in circular bioeconomy: a comprehensive review. Bioresour Technol 299:122585

Umemura K, Yanase K, Suzuki M, Okutani K, Yamoric T, Andoha T (2003) Inhibition of DNA topoisomerases I and II, and growth inhibition of human cancer cell lines by a marine microalgal polysaccharide. Biochem Pharmacol 66:481-487

Urso GD, Pizza C, Piacente S, Montoro P (2018) Combination of LC-MS based metabolomics and antioxidant activity for evaluation of bioactive compounds in Fragaria vesca leaves from Italy. J Pharm Biomed Anal 150:233-240

van Hal JW, Huijgen WJJ, Lopez-Contreras AM (2014) Opportunities and challenges for seaweed in the biobased economy. Trends Biotechnol 32:231-233

Volkman JK (2005) Sterols and other triterpenoids: source specificity and evolution of biosynthetic pathways. Org Geochem 36:139-159

Volk RB (2008) A newly developed assay for the quantitative determination of antimicrobial (anticyanobacterial) activity of both hydrophilic and lipophilic test compounds without any restriction. Microbiol Res 163:161-167

Wang B, Li Y, Wu N, Lan C (2008) $\mathrm{CO}_{2}$ bio-mitigation using microalgae. Appl Microbiol Biotechnol 79:707-718

Wei W, Kulkarni P, Liu K (2010) Integration of $\mathrm{H}_{2}$ /syngas production technologies with future energy systems. In: Liu K, Song C, Subramani V (eds) Hydrogen and syngas production and purification technologies. Wiley, Hoboken, pp 451-485

Wen ZY, Chen F (2003) Heterotrophic production of eicosapentaenoic acid by microalgae. Biotechnol Adv 21:273-294
Wicki A, Witzigmann D, Balasubramanian V, Huwyler J (2015) Nanomedicine in cancer therapy: challenges, opportunities, and clinical applications. J Control Release 200:138-157

Widowati I, Zainuri M, Kusumaningrum HP, Susilowati R, Hardivillier Y, Leignel V, Bourgougnon N, Mouget JL (2017) Antioxidant activity of three microalgae Dunaliella salina, Tetraselmis chuii and Isochrysis galbana clone Tahiti. In IOP Conf Ser Earth Environ. Sci, Vol 55, No. 1. IOP Publishing. pp. 012067

Williams MC, Strakey JP, Surdoval WA, Wilson LC (2006) Solid oxide fuel cell technology development in the U.S. Solid State lonics 177:2039

Wishart DS (2007) Current Progress in computational metabolomics. Briefings in Bioinformatocs 8:279-293

Wishart DS (2011) Advances in metabolite identification. Bioanalysis 3:1769-1782

Wooster O (2009) Waste to energy workshop: advances and opportunities for Ohio's. Livestock \& Food Processing Industries, Ohio

Xue M, Ge Y, Zhang J, Wang Q, Hou L, Liu Y, Li Q (2012) Anticancer properties and mechanisms of fucoidan on mouse breast cancer in vitro and in vivo. PLoS ONE 7:e43483

Yadav D, Sandeep K, Pandey D, Dutta RK (2017) Liposomes for Drug Delivery. J Biotechnol Biomater 7:1000276

Yen HW, Brune DE (2007) Anaerobic co-digestion of algal sludge and waste paper to produce methane. Bioresour Technol 98:130-134

Yuan JP, Peng J, Yin K, Wang JH (2011) Potential health-promoting effects of astaxanthin: a high-value carotenoid mostly from microalgae. Mol Nutr Food Res 55:150-165

Yusof YAM, Saad SM, Makpol S, Shamaan NA, Ngah WZW (2010) Hot water extract of Chlorella vulgaris induced DNA damage and apoptosis. Clinics 65:1371-1377

Zahan KA, Kano M (2018) Biodiesel production from palm oil, its by-products, and mill effluent: a review. Energies 11:2132

Zakaria SM, Kamal SMM, Harun MR, Omar R, Siajam SI (2017) Subcritical water technology for extraction of phenolic compounds from Chlorella sp. microalgae. Molecules 22:1-14

Zhang W, Tan NGJ, Li SFY (2014) NMR-based metabolomics and LC-MS/MS quantification reveal metal-specific tolerance and redox homeostasis in Chlorella vulgaris. Mol Biosyst 10:149-160

Zhang Y, Su H, Zhong Y, Zhang C, Shen Z, Sang W, Yan G, Zhou X (2012) The effect of bacterial contamination on the heterotrophic cultivation of Chlorella pyrenoidosa in wastewater from the production of soybean products. Water Res 46:5509-5516

Zheng LH, Wang YJ, Sheng J, Wang F, Zheng Y, Lin XK, Sun M (2011) Antitumor peptides from marine organisms. Mar Drugs 9:1840-1859

Zhu L (2015) Biorefinery as a promising approach to promote microalgae industry: an innovative framework. Renew Sustain Energy Rev 41:1376-1384

Zubia M, Fabre M, Deslandes E, Shannon C (2009) Antioxidant and cytotoxic activities of some red algae (Rhodophyta) from Brittany coasts (France). Botanic Mar. 52:268-277

\section{Publisher's Note}

Springer Nature remains neutral with regard to jurisdictional claims in published maps and institutional affiliations. 